\title{
PROSTITUCIÓN, ESTADO Y SOCIEDAD EN ESPAÑA. LA REGLAMENTACIÓN DE LA PROSTITUCIÓN BAJO LA MONARQUÍA DE ISABEL II (1854-1868)
}

\author{
Jean-Louis Guereña \\ Catedrático de Civilización Española Contemporánea \\ Instituto de Estudios Hispánicos, Université François Rabelais. Tours. (Francia)
}

\section{RESUMEN}

La monarquía isabelina, particularmente a partir del Bienio Progresista (1854-1856), contempló el retorno de la prostitución reglamentada tras dos siglos de abolicionismo oficial. Tras recordar los orígenes del reglamentarismo (1845-1847) y la reglamentación referida a Madrid, destacable por su importancia e influencia, se presentan las distintas normativas ensayadas en diversas regiones de España (notablemente en la provincia de Cádiz), siempre en una perspectiva cronológica que permita entender la génesis tanto administrativa como médica del sistema reglamentarista.

En vez de encerrar a la prostituta en una casa de corrección o de expulsarla de la ciudad como se había viniendo haciendo desde tiempos atrás, se la recluía en una casa de prostitución pretendiendo limitar su libertad de circulación y controlar periódicamente su potencial capacidad de contagio venéreo. Al mismo tiempo, la tolerancia de la prostitución confirmó el lugar y el papel de los burdeles en la vida social de las principales ciudades españolas.

\section{SUMMARY}

After two centuries of official abolitionism, the regulated prostitution came back during the reign of Isabella II and particularly from the Progresist period onwards (1854-1856). After recalling the origins of thuch regulations (1845-1847) and the rules applied in Madrid, which are worth noting because of their importance and influence, we are presenting the different decrees enforced in some regions of Spain (and particularly in the province of Cadix), in a chronological way which enables the reader to understand the formation, administrative and medical, of these regulations.

Instead of putting the prostitute in a house of correction or expelling her from the town as done before, these regulations would put her in a brothel, pretending that she would not move freely and that she would regularly be controlled concerning sexually transmitted deseases. The tolerance of prostitution confirmed as well the space and role of brothels in the social life of the main Spanish towns.

Entre represión y tolerancia, la reglamentación de la prostitución en los siglos XIX y XX, aún desconocida en buena parte en el caso español, ofrece una visión social acerca de la actividad prostitucional, a la que se condenaba en teoría (como 


\section{JEAN-LOUIS GUEREÑA}

"vil tráfico") a la par que se la toleraba en la práctica, pretendiendo regular sus condiciones de funcionamiento, no sin intentar sacar de ella, desde luego, alguna contrapartida económica bienvenida para unas haciendas no muy boyantes ${ }^{1}$.

La monarquía isabelina contempló el retorno de la prostitución reglamentada tras dos siglos de abolicionismo oficial. Aspectos policiales (la voluntad de erradicar elementos potenciales de desorden social) y sobre todo médicos (la preocupación creciente de los higienistas ante el gran miedo de las enfermedades venéreas ${ }^{2}$ ) confluyeron en la gestación de tal normativa que comenzó a generalizarse particularmente a partir del Bienio Progresista. Y el prostíbulo reglamentado vino a ser como el resultado de un compromiso estratégico entre Familia y Estado, en el seno de una sociedad de vigilancia y disciplina social ${ }^{3}$.

De cara a la reglamentación de la prostitución, como en otros tantos aspectos, la diversidad de las situaciones locales era claramente la regla en la época contemporánea española. "El Gobierno sabe esta situación, tan diversa en unas provincias que en otras", señalaba así en 1878 en sus Memorias hasta hace poco inéditas, un observador privilegiado y relativamente bien informado de las realidades administrativas de su tiempo, como podía serlo un Gobernador civil, "y sin embargo ni prohibe la reglamentación, antes al contrario lo tolera y consiente, especialmente en Madrid, ni la autoriza y generaliza en toda España; una u otra situación es la que debiera plantearse"4.

Y ante la casi total ausencia en España en el siglo XIX, de una legislación de conjunto sobre la prostitución, y a pesar de que los Códigos penales, tales como los de 1850 y de $1870^{5}$, se refirieran explícitamente a unos reglamentos policiales o

1 Ver nuestro primer trabajo general, "La réglamentation de la prostitution en Espagne aux XIXe et XXe siècles. Répression et réglamentarisme", en CARRASCO, Raphaël (Ed.), 1994, La prostitution en Espagne des l'époque des Rois catholiques à la IIe République, París, Les Belles Lettres (Annales Littéraires de l'Université de Besançon, 526), pp. 229-257, y nuestra tentativa de estado de la cuestión, GUEREÑA, J. L. (1997), "De historia prostitutionis. La prostitución en la España contemporánea", Ayer, Madrid, no 25, pp. 35-72, especialmente pp. 62-67 ("La cuestión de la reglamentación”).

2 QUÉTEL, Claude (1986), Le mal de Naples. Histoire de la syphilis, Paris, Seghers, pp. 135-163.

${ }^{3}$ FouCAult, Michel (1975), Surveiller et punir. Naissance de la prison, Paris, Gallimard (Bibliothèque des Histoires), pp. 137-158 y 197-229 (existe traducción española).

${ }^{4}$ GUEROla, Antonio (1993), Memoria de mi administración en la provincia de Sevilla como Gobernador de ella por segunda vez, desde 1 de Marzo hasta 5 de Agosto de 1878, Sevilla, Fundación Sevillana de Electricidad, Volumen II que comprende la Introducción y los tomos 1 y 2 de la Memoria de 1878, Sevilla, Fundación Sevillana de Electricidad, p. 291.

5 "Se castigarán con la pena de arresto de cinco a quince días, o una multa de 5 a 15 duros: (...) $8^{\circ}$ Los que infringieren los reglamentos de policía en lo concerniente a mujeres públicas" (Art. 485-8 del Código Penal de España. Edición oficial reformada, Madrid, En la Imprenta Nacional, 1850, p. 119); "Serán castigados con la multa de 5 a 25 pesetas y reprensión: (...) Los que infringieren las disposiciones sanitarias de policía sobre prostitución" (Art. 596-2 del Código Penal de 1870, en MARTínez ALCUBILLA, Manuel (1892), Diccionario de la administración española, peninsular y ultramarina, $5^{\text {a }}$ ed., t. 2, p. 960). 
sanitarios sobre el particular, se generalizaron al contrario, a partir de la segunda mitad del siglo las reglamentaciones de origen provincial (Gobernador Civil) en las capitales de provincia, o local (Alcalde) en las demás localidades, para intentar frenar el desarrollo de las enfermedades venéreas y vigilar la actividad prostitucional (siempre asociada al universo de la delincuencia) en el espacio de su respectiva competencia. Lo que no significaba, en un estado centralizado (o que pretendía serlo), que las autoridades superiores desconocieran tales normativas. Como poco, tuvieron que estar al tanto y dar su visto bueno.

Establecida la necesidad, o la "inevitabilidad" de tolerar la prostitución, se trataba por parte de las autoridades en el terreno de precisar dónde, cuándo, y cómo se podía ejercer la prostitución, pretendiendo erradicarla del espacio callejero urbano para encerrarla en un lugar específico bajo estrecha vigilancia, sin olvidar gravarla como cualquier actividad económica aunque sin reconocerla como tal.

¿Cómo, dónde y por qué se implantó el reglamentarismo en la época isabelina, particularmente desde el Bienio Progresista, cuando se puso en marcha realmente el sistema? Cabe aludir primero a los orígenes de la reglamentación en la década moderada, cuando se gestaron e implantaron las primeras normativas en la España contemporánea, antes de analizar el conjunto de la reglamentación elaborada de la Revolución de 1854 a la de 1868 . No presentamos aquí la reglamentación aplicada en Madrid - destacable por su importancia e influencia-, ya analizada en otro lugar ${ }^{6}$, para insistir en las distintas normativas ensayadas en diversas regiones de España, siempre en una perspectiva cronológica que permita entender la génesis, tanto administrativa como médica, del sistema reglamentarista, del espacio de tolerancia construido para la actividad prostitucional.

\section{LOS ORÍGENES DE LA REGLAMENTACIÓN EN LA ÉPOCA CONTEMPORÁNEA (1845- 1847)}

Dentro del movimiento reglamentarista contemporáneo, y dejando aparte el periodo de José I y de la ocupación francesa sobre el cuál disponemos de muy pocos datos concretos ${ }^{7}$, descuella claramente la reglamentación un tanto modélica aplicada

\footnotetext{
6 Ver nuestro trabajo "El tiempo de la prostitución reglamentada (Madrid, 1847-1909)", en El trabajo de las mujeres. Pasado y presente. Actas del Congreso Internacional del Seminario de Estudios Interdisciplinario de la Mujer, Ed. por $\mathrm{M}^{\mathrm{a}}$ Dolores RAMOS y $\mathrm{M}^{\mathrm{a}}$ Teresa BERA, Málaga, Servicio de Publicaciones de la Excma Diputación Provincial de Málaga, 1996, vol. II, pp. 53-75).

7 En Valladolid en Setiembre de 1809, según el diario de un testigo, "el Gobierno o Policía permitió mujeres prostitutas, matriculadas por tales y con señalamiento de casas" (GALLARDO, Francisco Noticia de casos particulares ocurridos en la ciudad de Valladolid, Año de 1808 y siguientes, Obra publicada, corregida, anotada y adicionada con un prólogo por D. Juan ORTEGA Y RUBIO, Valladolid,
} 


\section{JEAN-LOUIS GUEREÑA}

a Madrid, donde se publicó en Julio de 1847, tras un largo debate que arranca desde fines del siglo XVIII, el primer reglamento impreso sobre la prostitución que conocemos en España para la época contemporánea, y que sentaría las bases de la prostitución reglamentada: empadronamiento y vigilancia sanitaria periódica de las prostitutas.

Pero han de señalarse primero, y también durante la década moderada, las "Disposiciones" tomadas por el Gobernador civil de Zaragoza dos años antes, o sea en Marzo de 1845, "para la vigilancia de prostitutas y encubridoras"8. Tampoco hay que olvidar la preocupación temprana del Ayuntamiento de Cádiz por asegurarse del reconocimiento médico periódico de las prostitutas gaditanas, incluyendo un artículo sobre el particular en sus Ordenanzas municipales redactadas en Junio de 1845 . Señalemos también las medidas administrativo-policiales tomadas en Diciembre de 1847 por el Alcalde gaditano a instancias del Jefe político de la provincia para establecer listas de prostitutas y proceder a su reconocimiento médico9.

Ya en 1842, convencido el Ayuntamiento de Jaén "de lo relajada que se encuentra la moral pública por los desórdenes y escándalos producidos por las mujeres que hacen profesión de sus cuerpos con la mayor liviandad", y alarmado ante la progresión de las enfermedades venéreas, acordaron en Enero las autoridades municipales giennenses "que por los Señores Comisarios de Cuartel se adquieran noticias exactas de las mujeres dedicadas a esa vida y su procedencia", antes de decidir las medidas que convendrían adoptarse por la corporación municipal, medidas que ignoramos si llegaron a proponerse concretamente ${ }^{10}$.

En las ciudades más populosas o sedes de cuarteles, la prostitución iba entonces ganando cada vez más el centro de las poblaciones, despertando continuas protestas de los vecinos afectados, y moviendo a las autoridades locales, impotentes en erradicar la prostitución, a intervenir mínimamente para intentar "corregir" los "excesos" de la prostitución.

El bienio 1845-1847 nos aparece pues como un período clave para la génesis de la reglamentación de la prostitución en la España contemporánea, tanto desde el ángulo sanitario como policial. Se reunían entonces reunidas las condiciones para la elaboración de un reglamento específico fruto, sobre todo de la presión higienista.

Imp. y Librería Nacional y Extranjera de Hijos de Rodríguez, 1886, reimpresión facsímil en SANCHO, Hilarión, Gallardo, Francisco, MARTineZ, Demetrio (1989), Valladolid. Diarios curiosos (18071841), Valladolid, Grupo Pinciano-Caja de Ahorros Provincial de Valladolid, p. 197). Noticia recogida también por ALMUIÑA, Celso (1985), a quien agradecemos, en Historia de Valladolid, t. VI. Valladolid en el siglo XIX, Valladolid, Ateneo de Valladolid, p. 80.

8 Ver nuestro estudio (1997), "Los orígenes del reglamentarismo en España. La policía sanitaria de las mujeres públicas (Zaragoza, 1845)", Bulletin d'Histoire Contemporaine de l'Espagne, Aix-enProvence, $\mathrm{n}^{\circ} 25$, Junio, pp. 39-55.

9 A.M. Cádiz, exp. $\mathrm{n}^{\circ} \mathrm{C} / 1131$ (R).

${ }^{10}$ A.M. Jaén, Libro de Actas Municipales, Sesión de 25-I-1842. 


\section{PROSTITUCIÓN, ESTADO Y SOCIEDAD EN ESPAÑA....}

Sería en particular, tras las primerizas disposiciones zaragozanas, el dicho Reglamento para la represión de los escesos de la prostitución en Madrid, fechado en la capital en $1^{\circ}$ de julio de 1847 y que pretendía regular el ejercicio de la prostitución en la misma ${ }^{11}$, que contaba entonces con algo más de 200.000 habitantes, muchas tropas y un movimiento contínuo de población ${ }^{12}$.

Pero la práctica anterior de expulsión de las prostitutas de la ciudad seguiría siendo la medida más corriente. El Gobernador de Barcelona, Ventura Díaz ${ }^{13}$, podía así publicar en Junio de 1847 un Bando ordenando:

\footnotetext{
"Que a las mugeres públicas notablemente escandalosas se les haga marchar a los pueblos de su respectiva naturaleza, previniéndoles que si vuelven a presentarse en los que indebidamente viven se les castigará como desobedientes a la autoridad"14.
}

El general desconocimiento de esta temprana reglamentación prostitucional durante los primeros años de la monarquía de Isabel II, hace pensar en una confidencialidad casi absoluta, e ignoramos totalmente su posible alcance en la práctica, salvo en el caso zaragozano. Recogiendo hacia 1890 datos facilitados por M. Sanz Bombín, entonces Jefe del Cuerpo de Higiene y Sanidad, Enrique Rodríguez Solís, uno de los primeros historiadores de la prostitución en España, sólo mencionaba así para el año de 1847, y sin especificarlas —atribuyéndolas además a Juan (sic) Sabater-, "varias disposiciones relegando a las prostitutas a calles y casas determinadas del distrito del Hospital, donde eran reconocidas por profesores nombrados al efecto con idea de que las mujeres públicas fueran reconocidas"15. Tampoco se refería desde luego a las disposiciones zaragozanas de 1845 , que no merecieron ser objeto de una publicación.

${ }^{11}$ Reglamento para la represión de los escesos de la prostitución en Madrid, Madrid, Imprenta de Corrales y Compañía, 1847, 23 p. (Madrid, 1-VII-1847, El Gefe Superior Político, Patricio de la Escosura). Ver nuestro trabajo (1995), "Los orígenes de la reglamentación de la prostitución en la España contemporánea. De la propuesta de Cabarrús (1792) al Reglamento de Madrid (1847)", Dynamis, Granada, vol. 15, pp. 401-441.

12 Ver CARbajo IsLA, María F. (1987), El Censo de 1857 indicaba un total de 281.000 habitantes en Madrid (La población de la Villa de Madrid desde finales del siglo XVI hasta mediados del siglo XIX, Madrid, Siglo XXI, p. 225).

13 Desempeñó posteriormente la cartera de Gobernación en el Ministerio Istúriz (14 de Enero al 5 de Mayo de 1858).

14 DIAZ, Ventura, "Bando", 24-VI-1847, Boletín Oficial de la Provincia de Barcelona, n” 77, 28 VI-1847, p. 2.

15 RODRíGuez SOLís, E. (1893), Historia de la prostitución en España y América, Madrid, Imprenta de Fernando Cao y Domingo de Val, t. II, p. 180 (ver también la $2^{\mathrm{a}}$ ed., Biblioteca Nueva, s.f., (1921), pp. 243-244). Se trataba en realidad de Pedro Sabater, Jefe político de Madrid. 


\section{JEAN-LOUIS GUERENAA}

Tanto Monlau (Pedro Felipe Monlau, 1808-1871) como Magaz (Juan Magaz y Jaime, 1822-1901) ${ }^{16}$, polemizando en Setiembre-Octubre de 1847 sobre la reglamentación de la prostitución, o sea pocas semanas después de la publicación del reglamento madrileño de Patricio de La Escosura, ignoraban totalmente este primer intento, o por lo menos no lo mencionaban si es que llegaran a conocerlo ${ }^{17}$. Tampoco aludía a él, ni a las "disposiciones" zaragozanas en sus artículos de 1849 sobre las mancebías en España, Castellanos de Losada, no obstante estar relativamente bien informado ${ }^{18}$.

Y en 1853, interrogándose el higienista Francisco Méndez Alvaro (1806-1883) sobre "¿Qué reglamentos hay relativos a la prostitución en nuestro pais? ¿qué papel hace la policía sanitaria en presencia de un enemigo tan formidable y oculto como lo es la sífilis?"19, llegaba todavía a contestar rotundamente que "Nada tenemos en realidad", lamentando desde luego el retraso de España en la materia para con "todas las naciones cultas", y deseando "se estudie esta cuestión con madurez y (...) se adopten por fin los medios más conducentes para atajar los estragos de la enfermedad sifilítica". Si bien afirmaba entonces no desear la implantación de una reglamentación como la existente en otros paises, proponía como medidas inmediatas y

16 LoPez PiÑero, J. M. a , Glick, T. F., NAVARro Brotons, V., PORTEla MarCo, E. (1983), Diccionario histórico de la Ciencia moderna en España, Barcelona, Ediciones Península, t. 2, pp. 72-74 (Monlau), y pp. 13-15 (Magaz); GRANJEL, Mercedes (1983), Pedro Felipe Monlau y la Higiene española del siglo XIX, Salamanca, Universidad de Salamanca. Cátedra de Historia de la Medicina, 172 p.; CORBELLA, Jacint, DOMENECH, Edelmira (1991), "Análisis de algunos aspectos de la obra del doctor Juan Magaz y Jaime (1822-1901)", Actas del IX Congreso Nacional de Historia de la Medicina, Zaragoza, Universidad de Zaragoza, t. II, pp. 497-503.

${ }_{17}$ El Monitor de la Salud de las Familias y de la Salubridad de los pueblos. Revista de Higiene pública y privada; de Medicina y Economía domésticas; de Policía urbana y rural, etc., etc., punto VIII ${ }^{\circ}$ del artículo de P. F. MONLAU "De la prostitución y la sífilis" ("Una polémica sobre las mancebías", V, n 8, 15-IV-1862, pp. 86-91). Sobre la revista, ver GRANJEL, M., (1983), op. cit., pp. 150-157.

18 B. S. C. (= Basilio CASTELLANOS DE LOSADA), "De las mancebías en general y en particular de las españolas", El Foro español. Periódico de Jurisprudencia y de Administración, Madrid, t. I, ${ }^{\circ} 2,20$ I-1849, pp. 43-44; ${ }^{\circ} 3$, 30-I-1849, pp. 66-68; no 4, 10-II-1849, pp. 81-83; n ${ }^{\circ} 6$, 28-II-1849, pp. 136-140; $\mathrm{n}^{\circ} 7,10-\mathrm{III}-1849$, pp. 160-173; n 8 , 20-III-1849, pp. 174-177; n $13,10-\mathrm{V}-1849$, pp. $314-315 ; \mathrm{n}^{\circ} 17,20$ VI-1849, pp. 409-411; n 18, 30-VI-1849, pp. 419-425.

19 MÉNDEZ AlVARO, Francisco (1853), Consideraciones sobre la higiene pública, y mejoras que reclama en España la higiene municipal. Memoria presentada a la Real Academia de Medicina de Madrid, para su adhesión como socio de número, Madrid, Imprenta a cargo de José Rodríguez, pp. 77-78. Anunciaba entonces un "escrito especial" sobre este asunto, y aún en 1860 señalaba en su estudio sobre La lepra en España a mediados del siglo XIX. Su etiología y su profilaxia (Madrid, Imprenta de M. Rojas, 48 p.) que la profilaxis de la sífilis requería "un estudio amplio, esmerado, concienzudo y especial, que mal pudiera presentarse ahora como incidentalmente", añadiendo que iban "por otra parte unidas a él cuestiones graves y de solución difícil, que no es discreto ventilar ligera y precipitadamente" (p. 112 en la reedición parcial de la obra por FRESQUET FEBRER, José Luis (1990), Francisco Méndez Alvaro (1806-1883) y las ideas sanitarias del liberalismo moderado, Madrid, Ministerio de Sanidad y Consumo (Textos clásicos españoles de la salud públicas, 14). 


\section{PROSTITUCIÓN, ESTADO Y SOCIEDAD EN ESPAÑA....}

adecuadas a la situación española la admisión en los hospitales generales de los enfermos venéreos y la institución de consultas gratuitas y de socorros a las prostitutas ${ }^{20}$.

Bien es verdad que, descartando los dos precedentes algo aislados de 1845 y 1847, el arranque verdadero de la reglamentación prostitucional en España parece poder fecharse en 1854, a partir de la nueva coyuntura político-social abierta por la Revolución de Julio y el Bienio Progresista, - en el transcurso por cierto de una enésima epidemia de cólera—21, y más aún en 1859, ya bajo gobierno de la Unión Liberal. Nada o poco hubo pues que sepamos para lo que nos interesa, entre 1847 y 1854.

Apuntemos sin embargo que en 1849 una Comisión de médicos presidida por Mateo Seoane y compuesta por Quintín Chiarlone, Francisco Méndez Alvaro, Pedro Felipe Monlau, José Prada, Ramón Sánchez Merino y Leoncio Sobrado, o sea por partidarios (Sobrado) y adversarios (Monlau) de la reglamentación de la prostitución, elaboró un Reglamento de los Inspectores municipales de salubridad ${ }^{22}$. Entre las funciones de los Inspectores, figuraban las de "estudiar los mejores medios de conjurar la propagación de la sífilis", proponiendo a los Alcaldes "las medidas que al efecto conceptuen más oportunas", y practicando "los reconocimientos facultativos que convengan, según el estado de la prostitución pública en el pueblo de su residencia”, pero sin mencionar explícitamente cualquier reglamentación de la prostitución. Y la nueva Ley de Sanidad elaborada durante el Bienio, concretamente en 1855, no decía nada concreto sobre el tema, remitiendo, en cuanto a asuntos generales de Higiene pública, a un Reglamento específico ${ }^{23}$.

${ }^{20}$ Sobre Méndez Alvaro, ver LOPEZ PiÑERO, José $\mathrm{M}^{\mathrm{a}}$ (1964), "El testimonio de los médicos españoles dèl siglo XIX acerca de la sociedad de su tiempo. El proletariado industrial", en Medicina y Sociedad en la España del siglo XIX, Madrid, Sociedad de Estudios y Publicaciones, pp. 165-174; Diccionario histórico de la Ciencia moderna en España, op. cit., 1983, t. 2, pp. 51-53; y FRESQUET FEBRER, J. L. (1990), op. cit., 212 p. Sobre su opción a favor del reglamentarismo, ver CASCO SOLIS, Juan (1990), "La Higiene sexual en el proceso de institucionalización de la sanidad pública española", Asclepio, Madrid, vol. XLII, $\mathrm{n}^{\circ} 2$, p. 233.

${ }^{21}$ CONDE Gargollo, E. (1969), "Invasiones de cólera en la España del siglo XIX", Asclepio, Madrid, vol. XXI, pp. 113-120; PESET, M. y J. L. (1972), Muerte en España (Política y Sociedad entre la peste y el cólera), Madrid, Seminarios y Ediciones, pp. 213-231; FERNANDEZ GARCIA, Antonio (1977), "Repercusiones sociales de las epidemias de cólera del siglo XIX", Asclepio, Madrid, vol. XXIX, pp. 127-145; VINCENT, Bernard (1988), "Le choléra en Espagne au XIXe siècle", en Peurs et terreurs face à la contagion. Choléra, tuberculose, syphilis XIXe-XXe siècles, Paris, Fayard, pp. 43-55.

22 "Inspectores de salubridad", El Siglo Médico, Madrid, t. VII, n 346, 19-VIII-1860, pp. 540-541. La Comisión fue nombrada por Real Decreto de 15-IX-1849.

${ }^{23}$ Art. 98 en LOPEZ PIÑERO, J. M. (1984), M. Seoane y la introducción en España del sistema sanitario liberal (1791-1870), Madrid, Ministerio de Sanidad y Consumo (Textos clásicos españoles de la salud pública $\left.\mathrm{n}^{\circ} 12\right)$, p. 234. 


\section{LA REGLAMENTACIÓN MADRILEÑA (1854-1865)}

El reglamento elaborado para Madrid en $1865^{24}$, ha sido tradicionalmente considerado en la historiografía disponible sobre la cuestión como el primero en la materia en España ${ }^{25}$, aunque de hecho le precedieran otros dos reglamentos madrileños (en 1859 y en 1863), amén de una circular de 1854 y de un proyecto de 1855 , textos que por otra parte en nada se referían al reglamento de $1847^{26}$, y sin contar claro está con la reglamentación en provincias.

El papel de Madrid en la historia política del siglo XIX y la importancia de la reglamentación de la prostitución en la capital justifican ampliamente una aproximación específica. La población madrileña experimentó entonces una fuerte progresión, particularmente hasta 1860 , cuando contará con casi 300.000 habitantes ${ }^{27}$.

Notemos también que en diversas épocas fueron varios los ayuntamientos de provincias que solicitaron al de Madrid algún ejemplar del reglamento en vigor para

\footnotetext{
${ }^{24}$ Reglamento a que han de sujetarse todas las mujeres públicas residentes en esta Corte, con las Instrucciones necesarias para su cumplimiento, Madrid, Imprenta de D. Gregorio Hernando, 1865, 35 p.

${ }^{25}$ Fue traducido por el Dr. J. JEANNEL, De la Prostitution dans les grandes villes au XIXe siècle et de l'extinction des maladies vénériennes. Questions générales d'hygiène, de moralité publique et de légalité. Mesures prophylactiques internationales. Réformes à opérer dans le service sanitaire. Discussion des règlements exécutés dans les principales villes d'Europe, $2 \mathrm{e}$ éd. refondue et complétée par des documents nouveaux, Paris, J.-B. Baillière et Fils, 1874 ( $1^{\mathrm{a}}$ ed., 1868), pp. 467-470, y recogido por Amancio PERATONER en DUFOUR, Pedro (c. 1877), Historia de la prostitución en todos los pueblos del mundo, desde la antigüedad más remota hasta nuestros días. Obra necesaria para los moralistas, útil para los hombres de Ciencia y Letras, e interesante para todas las clases (Hasta el reinado de Luis XIV). Traducida, ampliada y continuada hasta nuestros días por Amancio PERATONER, Lujosa edición ilustrada con multitud de magníficas láminas por Eusebio PLANAS, Barcelona, Establecimiento tipográficoeditorial de J. Pons (Biblioteca hispano-americana), Parte última (t. II), s.f. pp. 1038-1043. Entre las obras de finales del XIX y principios del XX que se refieren al reglamento madrileño de 1865, ver FIAUX, Louis (1888), La police des moeurs en France et dans les principaux pays de l'Europe, París, E. Dentu, p. 590, y HAUSER, Ph. (1902), Madrid bajo el punto de vista médico-social. Su policía sanitaria, su climatología, su suelo y sus aguas, sus condiciones sanitarias, su demografía, su morbicidad y su mortalidad, Madrid, Establecimiento tipográfico "Sucesores de Rivadeneyra", reed., Madrid, Editora Nacional, 1979, vol. 2, pp. 136-137.

${ }^{26}$ Circular del Gobierno Político de Madrid, 4-XI-1854, 4 p. (impresa s. pie de imp.); Gobierno de la Provincia de Madrid, (Reglamento de la prostitución), Madrid, Imprenta Nacional, 1859, 7 p. (falta la portada); Reglamento de vigilancia especial de mujeres públicas, Madrid, Imprenta de D. V. Hernando, 1863, 19 p. RODRIGUEZ SOLIS, E. (1893), op. cit., señala la existencia de un Reglamento sobre la prostitución de 1858 dictado por el Marqués de la Vega de Armijo, "que él mismo reformó en el año de 1865" (t. II, p. 180), prosiguiendo que "la reglamentación de este vicio debió llevarse a cabo en la época del gobierno progresista, o lo que es igual, en el bienio de 1854 a 1856" (p. 182).

27 Ver FERNANDEZ GARCIA, Antonio y BAHAMONDE MAGRO, Angel (1993), "La sociedad madrileña en el siglo XIX", en A. FERNANDEZ (Ed.), Historia de Madrid, Madrid, Editorial Complutense, pp. 479-513.
} 


\section{PROSTITUCIÓN, ESTADO Y SOCIEDAD EN ESPAÑA....}

adaptarlo localmente, lo que demuestra cierto conocimiento y cierta circulación -por lo menos en los medios administrativos- de estos textos, a la vez que el papel matriz de la reglamentación madrileña.

El desarrollo de la venereología y de la sifiliografía como especialidades médicas específicas $^{28}$, y la constitución de un cuerpo de médicos higienistas ${ }^{29}$ (el Cuerpo Facultativo de Médicos inspectores de Salubridad pública fue creado no obstante, por oposición, en $1873^{30}$ ), iban a contribuir indudablemente a acentuar la presión higienista, cada vez más perceptible, y a arraigar aún más esta noción y este sistema de "Higiene especial".

A principios de este año de 1865, la Dirección General de Beneficencia y Sanidad del Ministerio de la Gobernación se había escindido precisamente en dos Direcciones, por el desarrollo alcanzado por ambos servicios, "sumamente importantes porque atienden, el primero a las necesidades de la clase menesterosa, y el segundo, a la conservación de la salud pública en todos los pueblos del Reino". Pero por Decreto de 25 de Junio de 1866 sólo quedaron cinco Direcciones Generales en el Ministerio, y en Julio de 1868 se redujeron a tres ${ }^{31}$.

Este reglamento madrileño de 1865 servirá a menudo de texto de referencia para las autoridades locales, incluso en fechas muy posteriores. El Alcalde de Gijón, aclarado por "varios vecinos" bien intencionados, preguntaba así al Gobernador civil de la provincia asturiana en 1882 "si el $\operatorname{art}^{\circ} 29$ del Reglamento aprobado en 14 de Nov. de 1865 por el Gobierno Civil de Madrid para la vigilancia de casas de mugeres públicas, en que se prescribe que no se toleran a inmediación de Cuarteles, Colegios de enseñanza, templos, fondas-Cafés y sitios muy transitados, puede considerarse de carácter general, dada la deficencia de otro derecho escrito"32.

\footnotetext{
${ }^{28}$ LLOPIS MÍNGUEZ, Baltasar (1990), Las publicaciones sobre venereología en la España isabelina (1834-1868) y su posición internacional, Tesis de doctorado, Universidad de Valencia, Facultad de Medicina, Cátedra de Historia de la Medicina, Agradecemos a su autor el habernos autorizado a consultar su trabajo aún inédito.

29 DE HONTAÑON, Pascual (1865), "Institución de los Médicos Higienistas. Resultados que deben esperarse de ella y medidas susceptibles de mejorarla", Crónica Médica. Periódico de medicina, cirugía y farmacia, Sevilla, vol. 35 , pp. 50-53 y 68-71.

${ }^{30}$ Reglamento de la Inspección de Salubridad pública en sus secciones de Higiene de las nodrizas y de la prostitución con las Instrucciones del cuerpo facultativo y el de vigilancia de la misma aprobado por el Excmo. Sr. Gobernador Civil de la Provincia en 31 de Julio de 1877, Madrid, Imprenta del Hospicio, 1877, p. div. (Inspección de Salubridad pública, p. 1 n.p.). Ver Dr. Benito AvILÉS (1893), Higiene pública según sus aplicaciones en España, $2^{\mathrm{a}}$ ed., Madrid, Establecimiento tipográfico de Enrique Teodoro, p. 148.

31 GARIJO AyestaRAn, María Josefa (1977), El Ministerio de la Gobernación (Materiales para un estudio de su evolución histórica hasta 1937), Madrid, Ministerio de la Gobernación, p. 68.

32 A.M. Gijón, Exp. $\mathrm{n}^{\circ} 173 / 1882$ y $175 / 1882$. No figura desgraciadamente la respuesta del Gobernador civil (entonces José María Diez Trigueros, en funciones del 26-IX-1881 al 20-X-1882). El Alcalde
} 


\section{JEAN-LOUIS GUERENA}

La reglamentación de la prostitución en España no se circunscribió desde luego a Madrid en esta primera etapa clave del reglamentarismo. Paralelamente a las distintas normativas madrileñas, y a menudo en relación muy directa con ellas, cabe señalar también para la época de la monarquía isabelina, precisamente a partir del Bienio Progresista y aparte pues de las "disposiciones" zaragozanas de 1845 y de las medidas gaditanas de fines de 1847, unos quince reglamentos referentes a varias localidades más o menos importantes en aquel entonces (de unos quince mil habitantes Gerona- a casi doscientos mil -Barcelona), de los que tenemos conocimiento más o menos directo. Ver cuadro recapitulativo al final.

La presión reglamentarista se acentuó pues indudablemente en la segunda mitad del siglo, sin duda a raiz de las periódicas epidemias de cólera que contribuyeron a desarrollar las preocupaciones higiénicas tanto en los políticos como en el seno de la sociedad, y frente a la importancia de las enfermedades venéreas. En 1850, aún podía quejarse sin embargo Ramón de La Sagra tanto del desarrollo de la prostitución como de la incuria generalizada de las autoridades frente a la cuestión:

\footnotetext{
"Así ha continuado y continua hoy día, casi del todo desatendida la organización de las casas públicas, cuyo número no obstante aumenta de un modo alarmante para las costumbres públicas, en las grandes ciudades de España. Al mismo tiempo, los progresos de la miseria en las clases medias que se han visto privadas de sus fortunas por la guerra civil; la reducción de los sueldos de los empleados, en cada cambio político que ha habido, y el desdén con que son miradas estas calamidades por el gobierno y las autoridades locales, hacen caer en el abismo de la prostitución a miles de jóvenes, y en los desórdenes de la corrupción moral a niñas apenas salidas de la primera infancia" ${ }^{33}$.
}

Pero cada vez más preocupadas por esta situación gangrenosa, las autoridades locales y provinciales empezaron a tener algo menos de "desdén" para con la prostitución y a intentar actuar de alguna forma, o sea a reglamentarla de Norte a Sur del país, no sin encontrar algunas resistencias, singularmente por parte de las autoridades

hacía referencia a un tratado no especificado del prolífico Fermín ABELLA (verosímilmente su Manual de policía urbana, 1877 , con una $2^{\mathrm{a}}$ ed. en 1887 , que efectivamente se refiere a la reglamentación de la prostitución en su cap. IV, "Moral pública, espectáculos y fiestas".-"Prostitución", pp. 341-346 y 377379 -"Formularios".-Prostitución.-Reglamento"-, y en su cap. VI, "Proyecto de Ordenanzas Municipales", Tít. I. Policía urbana, cap. I, Orden público, Sección 11. Prostitución, p. 508).

${ }^{33}$ DE LA SAGRA, (1850), Ramón Notas para la historia de la prostitución en España, Madrid, Imprenta de Don Antonio Mateis Muñoz, p. 15. Se trata de la versión española de una intervención en el Congreso de Higiene de Bruselas ("Notes pour servir à l'histoire de la prostitution en Espagne", Congrès général d'hygiène de Bruxelles. Session de 1852. Compte rendu des Séances.-Texte des Résolutions votées.-Appendice.-Plans, Bruxelles, Imprimerie de G. Stapleaux, 1852, pp. 402-415). 
eclesiásticas que asistían, más o menos impotentes, a la puesta en vigor del reglamentarismo, o sea a fin de cuentas de la legalización de la prostitución.

Prueba de todos modos del reconocimiento oficial de la existencia de las prostitutas fue su inclusión como tales en el censo de la población realizado en 1857, por lo menos en los documentos primarios ${ }^{34}$, ya que desgraciadamente los datos por profesión u ocupación no figuran en la publicación impresa por la Comisión de Estadística General del Reino:

\footnotetext{
"En la clasificación de los habitantes según sus profesiones y ocupaciones, se han experimentado tales tropiezos, ya por falta de costumbre, ya por la complicación resultante de figurar una misma persona repetidamente y por varios conceptos en las casillas de los padrones, que la Comisión (...) hubo de renunciar por ahora a semejante averiguación (...."35.
}

Pero significativamente, y reflejo de una tendencia constante, las prostitutas (las "mujeres públicas" según la terminología del censo y de la época) sí aparecían censadas localmente junto a otras poblaciones marginales como podían serlo los mendigos, los gitanos y los vagamundos, los dementes, los "idiotas", los ciegos y los sordomudos ${ }^{36}$.

\section{DURANTE EL BIENIO (1854-1856). PREVENCIONES EN GERONA Y DISPOSICIONES EN JEREZ}

Pocos años antes de la formación de este censo de 1857, y sólo unos meses tras la Revolución de 1854, fue el Ayuntamiento de Gerona (tan sólo 14.615 habitantes en $1857,14.341$ en 1860 y 15.787 en $1900^{37}$ ) quien procedió a reglamentar la prostitución en su localidad con diecinueve Prevenciones reglamentarias concernientes a la

34 JiMÉnEZ, Mª Rosa (1990), Espacio urbano y Sociedad. Estudio del Padrón Municipal Zaragozano de 1857, Zaragoza, Institución Fernando el Católico, p. 74.

35 Censo de la población de España según el recuento verificado en 21 de Mayo de 1857 por la Comisión de Estadística General del Reino, Madrid, Imprenta Nacional, 1858, p. VII. Ver también p. XXII.

${ }^{36}$ Era por ejemplo el caso en Jerez (A.M. de Jerez de la Frontera, legajo $\mathrm{n}^{\circ} 175$, expediente $\mathrm{n}^{\mathrm{o}}$ 9.743. Cortesía de Diego CARo CANCELA).

${ }^{37}$ La disminución de la población en 1860 con relación a 1857 debe de provenir de diferencias en la guarnición de la ciudad. Todos los datos de población proceden de los censos de población correspondientes ("población de hecho"). 


\section{JEAN-LOUIS GUEREÑA}

prostitución dictadas en el mes de Octubre por los Alcaldes Constitucionales de la ciudad Joan Balari y Josep Llach i Soliva ${ }^{38}$.

Era precisamente inmediatamente después de la epidemia de cólera (en los meses de Agosto-Octubre de 1854) que también afectó a Gerona como a todo el litoral mediterráneo, causando la muerte de 158 habitantes en la ciudad (algo más del 1\% de la población global) ${ }^{39}$. Y es muy posible que estas Prevenciones se tomaran dentro de un conjunto más amplio de medidas sanitarias.

La proximidad con Francia (Perpiñán está a menos de 100 kilómetros de Gerona) puede, claro está, explicar la formación de este reglamento (en el que se utilizaba por ejemplo el término de "casas de tolerancia", traducción directa del término francés "maisons de tolérance", que no tuvo mucha fortuna en España). También hay que tener en cuenta la presencia de una fuerza militar relativamente importante con relación a la población (un regimiento de infantería de 1.160 hombres -representando el $8 \%$ de la población global- estaba estacionado en la ciudad ${ }^{40}$ ). Tal vez efectuara alguna petición en torno a la vigilancia sanitaria de las prostitutas el Gobernador militar de la plaza, el Mariscal de campo Felipe Ruiz y Ruiz ${ }^{41}$.

¿Cómo se informó por otra parte al hasta entonces Jefe político de la provincia, Pedro Celestino Argüelles ${ }^{42}$, que no podía permanecer totalmente al margen de tales disposiciones, máxime en la capital de provincia? ¿Qué consignas más o menos directas pudo haber recibido? ¿Y con qué competencias podían dictar tal normativa los Alcaldes de Gerona ${ }^{43}$ ? Según la Ley municipal del 8 de Enero de 1845, siempre en

\footnotetext{
38 Alcaldía constitucional de la inmortal Gerona (Los Alcaldes Constitucionales Joan BALARI y Josep LLACH I SOLIVA), Prevenciones reglamentarias concernientes a la prostitución, Gerona, 26-X-1854, una hoja impresa (A.M. Girona, XXV. Diversa, leg. 6 (G-H), exp. "Higiene pública"). El texto es reproducido por CLARA, Josep (1981), "Girona a mitjan segle XIX: les cases de tolerància", Tercer Congrès d'Història de la Medicina catalana. Actes, Lleida, s.ed., vol. 1, pp. 96-98.

39 PORCAlla I DIOMER, J. (1859), Historia del cólera-morbo epidémico, que invadió la ciudad y partido de Gerona en el año 1854. Memoria premiada por la Academia de Medicina y Cirugía de Barcelona, Barcelona, Imprenta y Librería de Tomás Gorchs, 28 p.

40 Martinez Quintanilla, Pedro (1865), La provincia de Gerona. Datos estadísticos, Gerona, Imprenta de F. Dorca sucesor de J. Grases, p. 232.

${ }^{41}$ Guía de Forasteros en Madrid para el año de 1855, Madrid, En la Imprenta Nacional, p. 165.

42 Pedro Celestino Argüelles fue declarado cesante el 18-X-1854 (Gaceta de Madrid, 20-X-1854, y Boletín Oficial de la Provincia de Gerona, $\mathrm{n}^{\circ}$ 128, 25-X-1854, p. 1), tras su "corto, pero grave y azaroso periodo de (...) administración" (Circular n ${ }^{\circ} 487,24-\mathrm{X}-1854$, Ibid., $\mathrm{n}^{\circ}$ 128, 25-X-1854, p. 1). Santiago Picó fue nombrado el 5-XI-1854 (Adición al Boletín Oficial de la Provincia de Gerona, 6-XI-1854, 1 hoja). Ver Guía de Forasteros para 1855, op. cit., p. 418, y Guía de Forasteros en Madrid para el año de 1856, Madrid, En la Imprenta Nacional, p. 405.

43 Ver GuIRADO CID, Cristóbal (1991), El Alcalde en la legislación española, Madrid, Editorial Trivium, pp. 111-112, y JORJE TORRES, Francisco (1847), Guía de Alcaldes y Ayuntamientos, o sea Recopilación metódica, en que se consignan cuantos deberes y atribuciones competen a los alcaldes y ayuntamientos, especificándose clara y distintamente todas las actuaciones y diligencias así periódicas
} 
vigor diez años más tarde, correspondía en efecto al Alcalde "cuidar de todo lo relativo a policía urbana y rural, conforme a las leyes, reglamentos y disposiciones de la autoridad superior y Ordenanzas municipales"44. Y se hacía desde luego explícita referencia en el reglamento gerundense a varios artículos del Código Penal en vigor (entonces el de 1850), concretamente a los artículos $n^{\circ} 363$-párrafo $2^{\circ}, 365,366,367$, 374 (dentro del título X del libro II, "Delitos contra la honestidad") y al artículo ${ }^{\circ}$ 482-párrafo $2^{\circ}$, pero no al $\mathrm{n}^{\circ} 485$-parrafo $8^{\circ}$ al cual hemos aludido con anterioridad ${ }^{45}$.

Estas Prevenciones gerundenses presentadas materialmente bajo forma de un cartel (de 43.7 por $31.5 \mathrm{cms}$.) debían de ser colocadas "en tablón o cuadro" en la salarecibidor de las "casas de tolerancia" "a fin de que se cumpla lo mandado" (art. 19). El "empresario" (o "empresaria") de la casa de prostitución era en efecto responsable ante las autoridades, y debía de declarar a las prostitutas (art. 1).

Los elementos tradicionales de la reglamentación estaban presentes: empadronamiento y revisiones médicas (semanales en este caso) de las prostitutas. De cumplirse las prevenciones, tanto proxenetas como prostitutas no tendrían problemas por parte de las autoridades. En cambio se perseguiría "la prostitución clandestina o no tolerada por la Autoridad, y la seducción de mujeres honradas" (art. 17). El reglamento gerundense distinguía pues muy claramente entre las "rameras" y las "mujeres honradas", a quienes se trataba de "proteger". La prohibición de las "orgías" en los burdeles autorizados remitía claramente a una disciplina de la sexualidad. Nada pues de desorden sexual.

Estas Prevenciones gerundenses dejaron de ser válidas tras el Bienio, en momentos en que la crisis económica hizo sus estragos en la ciudad ${ }^{46}$, cuando "por disposición verbal del M. Y. Sr Gobernador Civil se mandaron cerrar los establecimientos, habiéndose recogido a sus dueños el Bando reglamentario"47. Y sólo sería durante el Sexenio - concretamente en 1869- cuando se volvería a reglamentar la prostitución en la ciudad ${ }^{48}$.

como eventuales que a los mismos corresponde ejecutar: con arreglo al testo literal de las leyes vigentes, y a la práctica seguida por el Ayuntamiento de Madrid, Madrid, Imprenta de Corrales y Compañía, Editores, t. I, pp. 382-383 ("Tratado IX. De la administración de los Alcaldes relativamente a la moralidad de los pueblos y a las costumbres públicas").

44 Art. 74-5, en MARTINEZ AlCUBILla, M. (1892), Diccionario de la administración española, op. cit., t. I, p. 796. Las últimas Ordenanzas gerundenses eran las de 1844 (Ordenanzas municipales de la ciudad de Gerona acordadas por el Excmo. Ayuntamiento de Gerona en el año de 1844, Gerona, Imp. de J. Grasses, 27 p.).

45 Código Penal de España, op. cit., 1850, pp. 92-94 y 117.

46 AlBERCH, Ramón y PORTELLA, Jaume (1968), "La crisi de subsistències del 1856-57", en Girona al segle XIX, Girona, Gothia Editorial, pp. 43-63.

47 A.M. Girona, XXV. Diversa, leg. 6 (G-H), exp. "Higiene pública".

48 ZAVALA, Justo María (1891), Consideraciones sobre la prostitución y sus reglamentos, Madrid, El Progreso Tipográfico, p. 71; E. RoDRIGUEZ SoliS, (1893), op. cit., t. II, p. 187. No hemos localizado dicho reglamento que no se conserva en el Archivo Municipal gerundense. 


\section{JEAN-LOUIS GUEREÑA}

Sin que podamos hablar realmente de un reglamento, la inclusión - también en 1854 - en las Ordenanzas municipales de la ciudad cordobesa de Montilla de un corto artículo referido a revisiones médicas de las prostitutas - adaptado de las Ordenanzas gaditanas de 1845 - revelaba seguramente más una voluntad del municipio que una realidad, pero no dejaba de ser sintomática:

\footnotetext{
"Los facultativos tienen el deber de poner en noticia del Alcalde las mujeres públicas que cayesen enfermas del mal venéreo para que sean conducidas al hospital y curadas allí, pagando ellas las estancias si tuviesen para ello"49.
}

Tras Gerona, un año más tarde y siempre tras una epidemia de cólera ${ }^{50}$, el municipio de Jerez de la Frontera (51.339 habitantes en 1857, 52.158 en 1860 y 63.473 en 1900), en la provincia de Cádiz, procedió a fines de Octubre de 1855 a reglamentar la prostitución, con ocho Disposiciones sobre las casas de mugeres públicas, propuestas por sus édiles Ramón de Cala y Manuel Maqueda para someter "todas las casas de mugeres públicas a dos reconocimientos facultativos semanales" 51 .

La ciudad quedaba dividida en seis distritos, cada una a cargo de un médico jerezano (Francisco de Paula Heredia, José Heredero, Antonio Jiménez, Cayetano López, Teodoro Orozco y José Rodríguez y Pasos), para la vigilancia sanitaria de las casas de prostitución. Debió de dar su visto bueno el entonces Gobernador provincial Francisco de los Ríos y Rosas, hermano mayor de Antonio, más conocido como político $^{52}$. ¿Qué pasó después del Bienio? ¿Siguió reglamentándose la prostitución por el nuevo equipo municipal? ?3 $^{3}$

49 Ordenanzas Municipales de Montilla, mss., 1854, art. 13 (A.M. Montilla, Leg. 910 B, exp. 1).

50 CARo CANCElA, D. (1991), "El cólera-morbo en Jerez: la epidemia de 1854", Trocadero, Cádiz, $\mathrm{n}^{\circ} 3$, pp. 117-155.

${ }^{51}$ Disposiciones para la aplicación de las bases acordadas por el M.I. Ayuntamiento sobre las casas de mugeres públicas, Jerez de la Frontera, s.imp., 1855, una hoja impresa ("El Alcalde $2^{\circ}$ Constitucional Presidente de la Comisión", 31-X-1855). Cortesía de CARO CANCELA, Diego (ver su trabajo "Una aproximación a la prostitución en el Jerez del siglo XIX", Comunicación presentada en el Coloquio de Historias Locales de Cádiz, Cádiz, Octubre de 1990, de próxima publicación, y Burguesía y Jornaleros. Jerez de la Frontera en el Sexenio Democrático (1868-1874), Jerez, Caja de Ahorros de Jerez, 1990, pp. 57-58).

${ }^{2}$ Guía de Forasteros para 1855, op. cit., p. 416; Guía de Forasteros para 1856, op. cit., p. 403. Fue posteriormente diputado por el distrito de Olvera, donde ejercía "una influencia omnipotente" (GuERola, A. (1986), Memoria de mi administración en la provincia de Cádiz, como Gobernador de ella desde el 31 de Marzo hasta el 31 de Mayo de 1863, Introducción por Federico SUAREZ, Cádiz, Caja de Ahorros de Cádiz, p. 45).

${ }^{53}$ No conocemos reglamento anterior al de 1876 (Reglamento para el servicio de Higiene especial de la ciudad de Jerez de la Frontera, Sevilla, Imp. de Gironés y Orduña, 1876, 16 p.). Ver A.M. Jerez, Leg $\mathrm{n}^{\circ}$ 220, exp. $\mathrm{n}^{\circ}$ 11.147: Expediente sobre regularizar el régimen sanitario en la prostitución (1875). 


\section{PROSTITUCIÓN, ESTADO Y SOCIEDAD EN ESPAÑA....}

También cabe señalarse entonces la existencia de un reglamento para la ciudad de Málaga (94.293 habitantes en 1855, 94.732 en 1860 y 130.109 en 1900), elaborado en 1855, tras una epidemia de cólera ${ }^{54}$, por el gobernador de la provincia Cayetano Cardero — destacado progresista que sería Gobernador de Madrid de Octubre de 1855 a Enero de $1856^{55}$ - , según testimonio recogido en sus documentadas memorias por Antonio Guerola, al frente del gobierno malagueño a partir de Diciembre de 1857:

\footnotetext{
"Cuando yo llegué a Málaga, había en práctica un reglamento de las casas de prostitución hecho por mi antecesor don Cayetano Cordero (sic) y reproducido por don Fernando Zappino. Era una completa autorización de este ejercicio con sus cartillas, su impuesto a las dueñas de las casas y a las pupilas y el reconocimiento sanitario hecho periódicamente sobre estas últimas" 56 .
}

Guerola suspendió inmediatamente la aplicación de este reglamento, "porque siempre he creído que en esta materia la autoridad puede tolerar, pero nunca autorizar, aunque la inspección sanitaria no puede dejar de ejercerse para evitar mayores males" 57 . También nos revela, caso frecuente en todo el siglo XIX, la utilización desviada de los fondos del servicio hacia otras necesidades administrativas:

“(...) Según el reglamento, con el impuesto que se exigía se formaba un fondo que lo administraba el depositario del Gobierno, destinado a pagar los médicos y las cartillas y el sobrante debía ir a beneficencia.

No había ido sin embargo cantitad alguna a beneficencia, y el fondo había servido para gastos de secretaría tanto de personal como de material".

\footnotetext{
54 JiMÉNEZ QUINTERO, José A. (1976), "La epidemia de 1854-55", Jábega, Málaga, no 16, pp. 29-34.

55 Ver GIL Novales, Alberto, Ed. (1991), Diccionario biográfico del trienio liberal, Madrid, Ediciones El Museo Universal, p. 127, y Guía de Forasteros para 1855, op. cit., p. 416. Había sido anteriormente Gobernador de Badajoz (Guía de Forasteros para 1842, p. 202) y de Zaragoza de Agosto a Diciembre de 1854 y de Julio a Octubre de 1855 (PInIlla NAVARro, Vicente (1985), Conflictividad social y revuelta política en Zaragoza (1854-1856), Zaragoza, Diputación General de Aragón (Colección "Temas de Historia Aragonesa", 2), p. 120, n. 23).

56 A. Guerola, (1995), Memoria de mi administración en la provincia de Málaga como Gobernador de ella desde 6 de Diciembre de 1857 hasta el 15 de Febrero de 1863, Introducción por Federico SUAREZ, vol. III, Sevilla, Fundación Sevillana de Electricidad, cap. 94, p. 953. Guerola olvida entre sus predecesores a Domingo Velo. No hemos localizado este reglamento.

57 En otra parte de sus Memorias referida a Sevilla, confiaba sin embargo que solía conservar la reglamentación de la prostitución que existía previamente a su llegada pero que él nunca la instauraba (Memoria de mi administración en la provincia de Sevilla, op. cit., 1993, vol. II, p. 291). "Es sabida mi ninguna afición a ocuparme de este ramo" aseguraba por otra parte en sus Memorias acerca de su gestión al frente de la provincia de Cádiz (Memoria de mi administración en la provincia de Cádiz, op. cit., 1986, p. 151).
} 


\section{JEAN-LOUIS GUERENA}

\section{Bajo La Unión LiBERAL (1859-1863). De SEVILla A BARCELONA}

El movimiento reglamentarista se aceleró en España a partir de 1859, durante la larga presidencia de la Unión Liberal con O'Donnell, gracias en parte a la adopción de la reglamentación madrileña aquel año (a fines de Abril) que sirvió en cierto modo de modelo a las demás, y al peso creciente del higienismo en una sociedad ya sensibilizada por las epidemias de cólera y alertada por la prensa del "cáncer" que podía representar la prostitución 58 .

Cabe señalar primero la reproducción por el ayuntamiento toledano de las Ordenanzas de la mancebía de Toledo de 1571 en las ordenanzas municipales impresas en 185859 .

En 1859, Sevilla (112.529 habitantes en $1857,118.298$ en 1860 y 148.315 en 1900) se incorporó en efecto al reglamentarismo con veinticuatro Disposiciones para prevenir los males que origina el ejercicio de la prostitución dictadas en Setiembre por el Gobernador civil de turno, Juan Jiménez Cuenca ${ }^{60}$, "en el deber de disminuir en lo posible cuantas causas puedan influir en debilitar la salud y constitución de muchos indivíduos y convencido de los funestos resultados que ocasionan las enfermedades que emanan de la prostitución, y que ofenden la buena moral y la decencia"61. Más detalladas que las jerezanas de 1855, estas Disposiciones sevillanas eran

58 "Cáncer”, La Andalucía, Sevilla, 15-IX-1858, cit. por VAZQueZ GARCIA, Francisco y MORENO MENGIBAR, Andrés (1996), Poder y prostitución en Sevilla (Siglos XIV al XX). Tomo II La edad contemporánea, Sevilla, Universidad de Sevilla (Colección de bolsillo $\mathrm{n}^{\circ}$ 145), pp. 96-97.

59 Ordenanzas para el buen régimen y gobierno de la muy noble, muy leal e imperial ciudad de Toledo, Toledo, Imprenta de José de Cea, 1858, título 93 (De las mujeres de la mancebía), pp. 150-153. Artículos reproducidos por El Monitor de la Salud de las Familias y de la Salubridad de los Pueblos, Madrid, IV, $\mathrm{n}^{\circ}$ 10, 15-V-1861, pp. 109-111.

${ }^{60}$ Guía de Forasteros en Madrid, para el año de 1859, Madrid, Imprenta Nacional, p. 438; Guía de Forasteros en Madrid, para el año de 1860, Madrid, Imprenta Nacional, 1860, p. 446. Jiménez Cuenca había sido anteriormente Gobernador de las provincias de Orense (Guía de Forasteros para 1855, op. cit., p. 419) y de Palencia (Guía de Forasteros en Madrid, para el año de 1858, Madrid, Imprenta Nacional, p. 431).

${ }^{61}$ Disposiciones adoptadas por el Gobierno de la provincia de Sevilla para prevenir los males que en esta capital origina el ejercicio de la prostitución, Sevilla, Imprenta del PORVENIR, 1859, 6 p +3 p. no num. (cita en la p. 3). Ver el documentado estudio de VAZQUEZ GARCIA, F. y MORENO MENGIBAR, A. (1991), "Biopolíticas del placer en España. Documentos sobre la prostitución en Sevilla ( ${ }^{a}$ parte): las reglamentaciones del siglo XIX", Er. Revista de Filosofia, n ${ }^{\circ} 11,1991$, pp. 153-192, y de los mismos su reciente Poder y prostitución en Sevilla, op. cit., pp. 96-117. 


\section{PROSTITUCIÓN, ESTADO Y SOCIEDAD EN ESPAÑA....}

muy similares de hecho al reglamento madrileño publicado unos meses antes ${ }^{62}$, y serían sustituidas durante el Sexenio seguramente ante su falta de aplicación ${ }^{63}$.

Alarmadas ante el desarrollo de la prostitución callejera e inquietas ante los excesos de las medidas policiales aún en vigor, frecuentemente denunciadas por la pren$\mathrm{sa}^{64}$, las autoridades municipales hispalenses (pero el informe va dirigido conjuntamente al Gobernador y al Alcalde, García Vinuesa) se decidieron a solicitar en Marzo de 1858 al novel Colegio Médico de Sevilla, fundado cuatro años antes, y curiosamente no a la vieja Academia de Medicina y Cirugía, un informe sobre las medidas a adoptar para combatir los efectos de la prostitución. Partidario declarado de la reglamentación, el Colegio elaboró a fines de Enero de 1859 su informe con un primer proyecto de reglamentación de 38 artículos que serviría de base a las Disposiciones adoptadas en Setiembre junto con el reglamento madrileño de Abril65. Basándose en el Código Penal ${ }^{66}$, así como en el Código Civil que autorizaba el matrimonio de la mujer a los 12 años, el Colegio opinaba que "a los 12 años cumplidos puede una mujer ser inscrita en el registro", debiéndose comprobar sin embargo para las menores de 23:

\footnotetext{
" $1{ }^{\circ}$. que a este acto concurre espontánea y voluntariamente, sin insinuación, consejo, promesa o amenaza de persona extraña; y $2^{\circ}$, que se encuentra dotada de robustez y buena constitución física. En las que sean menores de 16 años, deberá acreditarse además el consentimiento de sus padres, tutores o encargados"67.
}

El incumplimiento de las disposiciones dictadas por el Gobernador, o posibles problemas de competencia entre autoridades provinciales y municipales, movieron a estas últimas a proponer en Setiembre de 1860 la elaboración de un Reglamento de

62 El reglamento madrileño se encuentra en el Archivo Municipal de Sevilla (Col. Alfabética, Médi$\cos -\mathrm{I})$ junto con las Disposiciones sevillanas.

${ }^{63}$ Reglamento de higiene especial y vigilancia sobre las casas de lenocinio y mujeres públicas, Sevilla, Imprenta de El Porvenir y Boletín Oficial, 1870, $19 \mathrm{p}$.

${ }^{64}$ SAÑA, D. (1858), "Cuestión candente", La Andalucía, Sevilla, 4-III-1858, cit. por VAZQUEZ, F. y MORENO, A. (1996), Poder y prostitución en Sevilla, op. cit., pp. 97-100.

65 Colegio Médico de Sevilla, "Informe" y "Reglamento orgánico de policía y sanidad respecto de la prostitución" (Sevilla, 31-1-1859), precedidos de una exposición (Sevilla, 17-II-1859), La Crónica Médica. Periódico de medicina, cirugía y farmacia, Sevilla, 1864, pp. 275-280 y 295-297. Entre los médicos del Colegio, citemos a su secretario José Moreno Fernández (1825-1900) -ver Diccionario histórico de la ciencia moderna en España, op. cit., 1983, t. II, pp. 85-86- y a su decano Antonio Serrano, firmante de la exposición.

66 Art. 363 y 366-367, Código Penal, op. cit., 1850, pp. 92-93.

67 "Reglamento orgánico de policía y sanidad respecto de la prostitución", op. cit., tít. 2, art. 7, p. 280. Ver "Informe", op. cit., p. 279. Estas disposiciones no se recogen en las Disposiciones. 


\section{JEAN-LOUIS GUEREÑA}

Higiene pública a Carlos Montemar68, miembro del reciente cuerpo de médicos higienistas de Madrid, sin llegar a aprobarlo69. La decidida oposición a toda reglamentación del higienista Manuel Pizarro y Giménez (1821-1892), seguidor de Monlau, contribuyó sin duda, junto a las críticas publicadas en la prensa a la gestión del servicio, a la paralización del reglamentarismo en Sevilla ${ }^{70}$.

En 1860, la ciudad de Alicante (31.162 habitantes en 1860 y 50.142 en 1900) imitó a la capital andaluza con la publicación de un reglamento "sobre higiene y vigilancia de casas y mugeres públicas", que no hemos podido consultar ${ }^{71}$. Celestino Más y Abad era entonces el Gobernador de la provincia ${ }^{72}$.

En Abril de 1861, le siguió el Ayuntamiento de Cádiz (71.521 habitantes en 1860 y 69.382 en 1900), tras las primeras medidas de 1847 seguramente olvidadas por aquel entonces, con un Reglamento represivo de la prostitución de 31 artículos ${ }^{73}$,

68 CARrillo Martos, Juan Luis (1993),"Medicina y enseñanza de la Medicina en Sevilla (18681883). Continuidad y cambio", en Historia de la Medicina Sevillana, Sevilla, Publicaciones de la Sociedad Nicolas Monardes, pp. 277 y 294.

${ }^{69}$ Montemar redactaría un Proyecto para la organización de un Cuerpo de Médicos Higienistas, Sevilla, 6-XII-1860 (A.M. Sevilla, Col. Alfabética, Médicos (I).

70 PIZARRO Y GIMÉNEZ, Manuel (1863), Bases para la organización del servicio sanitario municipal de Sevilla. Memoria escrita y presentada al Exmo. Ayuntamiento Hispalense, Sevilla, Est. Tip. de LA ANDALUCIA, 1861, 118 p., y Anuario de higiene pública. Exposición de las principales tareas y progresos de esta ciencia en el año de 1862, Sevilla, La Andalucía, pp. 127-140. Ver VAZQUEZ, F. (1996) у MORENO, A. (1996), Poder y prostitución en Sevilla, op. cit., pp. 117-131, y SANTAMARIA, Encarnación "La tradición ambientalista en la medicina hispalense de los siglos XVIII-XIX: de la Regia Sociedad a la obra de Hauser", en CARRILlO Juan L., (Ed.), Entre Sevilla y Madrid: Estudios sobre Hauser y su entorno, Sevilla, Imprenta A. Pinelo, pp. 154-156.

${ }^{71}$ Reglamento sobre higiene y vigilancia de casas y mugeres públicas, Alicante, Imp. de la V. de Carratalá, 1860, 8 p. (cit. por RICO GARCIA, Manuel (1961), Bosquejo histórico de la imprenta en Alicante en el siglo XIX, Alicante, Comisión provincial de monumentos históricos, p. 48, $\mathrm{n}^{\circ} 163$ ). No figura en los principales archivos y bibliotecas públicas de Alicante (ver Bibliografia de la Ciudad de Alicante, Alicante, Patronato Municipal del Quinto Centenario, 1990, 412 p.). Agradecemos la ayuda prestada por $\mathrm{M}^{\mathrm{a}}$ Jesús Paternina Bono, Archivera-Bibliotecaria municipal.

${ }^{72}$ Guía de Forasteros para 1860, op. cit., p. 446. Había sido anteriormente Gobernador de la provincia de Badajoz (Guía de Forasteros en Madrid, para el año de 1857, Madrid, Imprenta Nacional, p. 403) y de Toledo (Guía de Forasteros para 1858, op. cit., p. 429; Guía de Forasteros para 1859, op. cit., p. 438). Lo será posteriormente de Cádiz, donde, según indicación de su sucesor, reglamentaría la prostitución (GUEROLA, A., Memoria de mi administración en la provincia de Cádiz, op. cit., 1986, p. 151), y de Valencia (Guía de Forasteros para el año de 1865, Madrid, Imprenta Nacional, p. 684). Abogado, Más y Abad publicó a partir de 1844 varias Guías administrativas y jurídicas, destinadas en particular a Alcaldes.

73 A.M. Cádiz, Actas capitulares, 1861, t. I ( $\left.\mathrm{n}^{\circ} 10.272\right)$, Sesiones de 5-03-1861, fol. $215 \mathrm{v}^{\mathrm{a}}-232 \mathrm{r}^{\circ}$ (presentación del dictamen de la Comisión del 28-02-1861), 12-04-1861, fol. 344v $\mathrm{v}^{\mathrm{a}}-346 \mathrm{v}^{\mathrm{a}}$ (discusión y aprobación de los art. 1-9), y de 30-04-1861, fol. 378 $\mathrm{v}^{\mathrm{a}}-379 \mathrm{v}^{\mathrm{a}}$ (art. 10-31). Ver GONZALEZ JIMÉNEZ, Pedro (1993), "La prostitución en el Cádiz isabelino", Gades, Cádiz, n 21, pp. 133-141 (con múltiples 
también inspirado del precedente madrileño de 1859 , y redactado por una comisión compuesta por el Regidor Síndico Miguel Ayllón y Altolaguirre, inspirador del proyecto ${ }^{74}$, y los médicos Andrés J. Azoparde, Manuel Barrocal, José $\mathrm{M}^{\mathrm{a}}$ Fita $^{75}$, y José P. Pérez. En la exposición de su proyecto, la comisión argumentaba el calificativo de "represivo" aplicado al reglamento, defendiéndose de autorizar sin más la prostitución:

\footnotetext{
"Verdad es que la adopción de reglas seguras y constantes, partiendo del hecho de la prostitución, significa en rigor organizar, pero tampoco lo es que la condición esencial de toda organización, es la represión y en este concepto tan sólo, puede fijarse la vista en la prostitución sujetándola a reglas que, a la par que la dificulten, garanticen a la sociedad de la atenuación de algunos de sus efectos.

(...) Concentrar la prostitución para conocerla, vigilarla de cerca, visitar facultativamente a las mujeres dedicadas a ella, y castigar por último las infracciones del Reglamento, son por hoy a juicio de la Comisión, los medios represivos que pueden emplearse".
}

Una "Comisión inspectora", compuesta por un teniente de Alcalde, el inspector de vigilancia y tres médicos, y "subordinada" al Gobernador, quedaba encargada de velar por el cumplimiento del reglamento. Debía de redactar además una memoria anual al Gobernador "relativa al estado comparativo de la prostitución, haciendo en ella mérito del núm ${ }^{\circ}$ de casas y prostitutas, edades y estado de éstas, resultados de los reconocimientos semanales, enfermas separadas del tráfico, penas impuestas, y motivo de ellas, y cuantas circunstancias en su juicio importantes, merezcan atención”. A pesar de ser el Ayuntamiento el iniciador del reglamento, correspondía en efecto al Gobernador no sólo el aprobarlo sino también el aplicarlo, lo que confirman varios artículos del reglamento (art. 2, 8, 14, 23, 24 y 29).

Sería pues Celestino Más y Abad, Gobernador de la provincia hasta Febrero de 1863 y que ya había reglamentado la prostitución en Alicante en 1860, el encargado

errores de transcripción). Ignoramos si se publicó una versión impresa del mismo. Apuntemos que durante la discusión del proyecto, Fermín Salvochea (padre) se opuso en varias ocasiones al mismo, así como el demócrata Juan José Junco (ver MARChENA DoMinguEZ, José (1992), El Partido Demócrata Gaditano (1849-1868), Cádiz, Fundación Municipal de Cultura, pp. 131-133).

74 El 11-I-1861, proponía al Ayuntamiento "el nombramiento de una Comisión para que estudiando el asunto de que se trata, proponga a semejanza de lo (que) se halla establecido en la Villa y Corte de Madrid, la matrícula de las mugeres públicas, y los demás medios consiguientes a facilitar la vigilancia severa sobre las mismas, encaminada a mejorar la salud pública, en lo referente a este asunto" (A.M. Cádiz, Actas capitulares 1861, t. I, $\mathrm{n}^{\circ}$ 10.272, Sesión de 11-I-1861, Punto 10, fol. 48 $\mathrm{r}^{\circ}$ ). Ayllón Altolaguirre era presidente del Ateneo de Cádiz creado en 1858.

75 Sería el Jefe de los Médicos Higienistas en 1863 (Guerola, A. (1988), Memoria de mi administración en la provincia de Cádiz, op. cit., p. 64). Según DE HONTAÑON, P. (1866), había escrito un trabajo permanecido inédito sobre la prostitución y la profilaxis de la sífilis (Pascual DE HONTAÑON, Ensayo práctico sobre las enfermedades venéreas y sifilíticas, Cádiz, Imprenta de la Revista Médica, vol. 2, p. 662). 
de poner en aplicación el reglamento gaditano, sin que sepamos las eventuales modificaciones aportadas por él al proyecto municipal76:

\footnotetext{
"El reglamento consistía en el empadronamiento y en el reconocimiento sanitario, ambos retribuidos. Del empadronamiento se cobraba alguna cantidad que se invertía en objetos del servicio, pero eran cantidades de pequeña importancia"77.
}

Junto con el reglamento, la comisión proponía varias medidas para frenar el desarrollo de la prostitución, entre las cuales "la creación de una Sociedad de Señoras, encargada de la noble misión de iniciar a los desgraciados seres de que se trata en las verdades de nuestra Religión, instruyéndolas en el conocimiento de los más principales deberes de su sexo, educándolas en lo posible para poderse dedicar a labores determinadas, y combinándose estos trabajos tan importantes y esta tan provechosa instrucción, efecto de la creación de dicha Sociedad, con la de un establecimiento en el cual se atendiera a la subsistencia de las que se consiguiera apartar de la senda del vicio". En ese mismo año de 1861 , se creaba precisamente en la capital gaditana, "por el celo del P. D. Manuel M. Martínez", una casa de "recogidas", el denominado Asilo del Buen Pastor, establecido en el antiguo convento de los Descalzos ${ }^{78}$.

También se realizó entonces una campaña de prensa (concretamente en La Armonía) para conseguir el cierre de algunas casas de prostitución en la ciudad, obteniendo aparentemente satisfacción ${ }^{79}$. Notemos también que en 1863 la Guardia civil realizó tres capturas por delitos referidos a la prostitución sobre un total de 1.834 efectuadas en toda la provincia de Cádiz ${ }^{80}$.

En 1862, el Ayuntamiento de Santander (30.202 habitantes en 1860 y 54.694 en 1900) adoptó su propio reglamento de 27 artículos, también clara imitación del de

76 P. de Hontañón le atribuye desde luego la creación en la provincia de la institución de los médicos higienistas (Ensayo práctico sobre las enfermedades venéreas, op. cit., 1866, vol. 2, p. 666).

77 GUEROlA, A. (1986), Memoria de mi administración en la provincia de Cádiz, op. cit., p. 151.

78 RosetTy, José (1866), Guía de Cádiz, El Puerto de Santa María, S. Fernando, y el Departamento, para el año de 1866. Año XII, Cádiz, Imprenta y Litografía de la Revista Médica, p. 64.

79 La Armonía, Cádiz, no 29, 20-VIII-1861 (cit. por RAMOS SANTANA, Alberto (1987), La burguesía gaditana en la época isabelina, Cádiz, Fundación Municipal de Cultura, p. 439). Se publicaba a fines de Diciembre de 1861 un total de 22 publicaciones periódicas en la provincia (Anuario Estadístico de España, publicado por la Junta General de Estadística. 1860: 1861, Madrid, Imprenta Nacional, 18621863, pp. 438-439). En 1863, dirigida por Pedro Portillo, La Armonía se publicaba tres veces al mes (GUEROlA, A. (1986), Memoria de mi administración en la provincia de Cádiz, op. cit., p. 57).

80 Comandancia de la Guardia Civil en la provincia de Cádiz, "Estado de las capturas verificadas por la fuerza de mi mando en esta provincia en todo el año 1863 (Cádiz, 4-I-1864, el Capitán Comandante accidental, MECHACA Y MAJEO, Antonio de)", Boletín Oficial de la Provincia de Cádiz, n ${ }^{6}$, 7-I1864, p. 1 . 
Madrid de 185981. El penúltimo artículo por ejemplo recordaba -reproducción casi literal del artículo 25 del reglamento madrileño- que las disposiciones reglamentarias tenían "sólo por objeto evitar en lo posible los males del tráfico inmoral de que se trata, sin que se entienda dispensar protección en lo más mínimo a unos actos reprobados por la religión católica, única que se reconoce en España".

Gracias al hecho de que la reina Isabel II eligiera Santander como lugar de veraneo en 1861, las playas santanderinas se pusieron entonces de moda. La actividad portuaria, tanto comercial como de viajeros, contribuyó también a concentrar temporalmente allí a una clientela potencial de los prostíbulos.

Un proyecto de reglamento redactado por el Negociado de Orden público de la provincia de Baleares - "con muy ligeras variaciones el que fué publicado en Madrid en 30 de abril de 1859"- vió también la luz a fines de 1862 en Palma de Mallorca (53.019 habitantes en 1860 y 63.937 en 1900), "con la intención muy laudable de evitar en cuanto sea posible los perniciosos efectos de la prostitución, e impedir que ella sea objeto de escándalos" 82 . Si bien el Consejo provincial consultado ratificaba en Enero de 1863 la necesidad de tal reglamentación, llamaba no obstante la atención del Gobernador, Matías Edmundo Tirel, Marqués de Ulagares ${ }^{83}$, sobre algunos puntos importantes de la misma, en particular la responsabilidad de la inscripción y radiación del registro específico:

\footnotetext{
“QQuién califica las prostitutas o las mujeres que han de ser registradas, y que han de sujetarse al reconocimiento? ¿Quién debe declararlas excluídas de las prescripciones del reglamento?".
}

Parece ser que dicho proyecto se concretó, ya que unos diez años más tarde, acusando recibo de la comunicación de la Junta Municipal de Sanidad "referente a la necesidad de disponer lo que crea oportuno a fin de que sean vigiladas las mugeres inscritas en el registro de prostitución", el Gobernador de Baleares contestaba que "desde que tomé posesión del mando superior de esta provincia ha llamado muy especialmente mi atención el ramo de higiene pública, en especial en lo referente a la

\footnotetext{
${ }^{81}$ Reglamento de prostitución, s.l. (Santander), s. impr., s.f. (1862), 6 p. no p. Una nota manuscrita en el ejemplar consultado (Archivo Municipal de Santander) precisa la fecha.

82 Dictamen del Consejo Provincial, acerca la inconveniencia de reglamentar las prostitutas de Palma del modo que proponía el gobernador político Marqués de los Ulagares, 10-I-1863, en Bover, Misceláneas, t. XVIII, p. 458 (Biblioteca March, Palma), PASCUAL, Misceláneas, t. IX, p. 415 (Archivo del Reino de Mallorca, Palma), y VAQuer BenNASAR, Onofre (1987), La Sexualitat a Mallorca. Documents històrics, Mallorca, L'Obrador del llibre, pp. 50-52. No hemos localizado el documento original correspondiente.

${ }^{83}$ Había sido Gobernador de Guipúzcoa en 1860 (Guía de Forasteros para 1860, op. cit., p. 447).
} 
vigilancia de las casas de prostitución". "A este fin", añadía, "aumenté nuevamente este servicio con otro facultativo, cuya plaza había sido suprimida y encargué a los dependientes de mi autoridad todo el celo y la vigilancia necesarios para el mejor cumplimiento de las ordenanzas vigentes" 84 .

En 1863 hizo, al parecer, lo propio Barcelona (189.948 habitantes en 1860 y 533.000 en 1900), y aparentemente por primera vez, sin que hayamos podido dar con el eventual reglamento correspondiente ${ }^{85}$. El entonces Gobernador de la provincia, Francisco Sepúlveda Ramos ${ }^{86}$, nombró en efecto aquel año una Comisión facultativa bajo la presidencia del práctico Juan Durán y Sagrera, a la sazón Director de Sanidad marítima ${ }^{87}$, encargándole la confección de un reglamento que, "sosteniendo incólumes los principios de la moral, tendiera en lo posible a disminuir los estragos que la sífilis causaba en la población barcelonesa" ${ }^{88}$. ¿Vió entonces la luz este reglamento o

\footnotetext{
84 Oficio del Gobernador Civil de Baleares al Alcalde de Palma, 27-XI-1872 (A.M. Palma, Leg. 1534-XVIII). El reglamento posterior sería el de 1885 (Reglamento de la Sección de Higiene del Gobierno Civil de las Baleares, Palma, Imprenta de la Casa de Misericordia, 1885, 39 p.).

${ }^{85}$ MARSILlaCh Y PARERA, Juan (1869), Tema $n^{o} 36$ ¿Qué medios deberá aconsejar el médicohigienista al Gobierno para atenuar los funestos efectos ocasionados por la prostitución? Memoria que en ejercicio para el grado de doctor en Medicina y Cirugía leyó el día $1^{\circ}$ de Julio de 1869 D. --, Barcelona, Establecimiento tipográfico de Jaime Repús Roviralta, p. 16. Ver también el Reglamento orgánico del cuerpo de vigilancia pública, 21-X-1863, op. cit., art. 10.

${ }^{86}$ Nacido en Salamanca en 1819, había sido en 1854 Secretario del Gobierno de Zaragoza donde pudo haber conocido de cerca el sistema reglamentarista allí implantado (Guía de Forasteros para 1855, op. cit., p. 416), y Gobernador de las provincias de Teruel en 1855 (Guía de Forasteros para 1856, op. cit., p. 406), de Córdoba en 1856, de Canarias en 1857, de Zamora de 1858 a 1860 (Guía de Forasteros para 1859, op. cit., p. 440; Guía de Forasteros para 1860, op. cit., p. 448), de Alicante en 1861 y de Granada en 1862 (RISQUES CORBELLA, Manuel (1995), El govern civil de Barcelona al segle XIX, Barcelona, Publicacions de l'Abadia de Montserrat (Biblioteca Abat Oliva, 162), p. 620). Nombrado Gobernador de Barcelona el 28-I-1863, tomó posesión de su cargo el 15-II-1863, cesando el 31-I-1864, y volviendo de nuevo a ocupar el cargo, primero interinamente, de Julio a Octubre de 1864. Posteriormente se dedicó a asuntos comerciales y financieros (en el Crédito Mercantil en particular), muriendo en Madrid en 1894 (ver OVILO Y OTERO, Manuel (1859), Manual de biografía y de bibliografía de los escritores españoles del siglo XIX, Paris, Rosa y Bouret, t. II, p. 203, y Enciclopedia Universal Ilustrada, Madrid, t. 55, p. 413).

87 Obtuvo su doctorado en el Colegio de Cirugía de Barcelona en 1840 (Libro de Doctoramientos del R. C. de Cirugía de Barcelona, mss., B.U. de Barcelona, fol. 41.-Cortesía de José Danón), y fue redactor del Repertorio Médico. Periódico mensual que publica la Sociedad de Emulación de Barcelona en 1842-1844, junto con Pedro Mata y otros (MÉNDEZ ALVARO, F. (1883), Breves apuntes para la historia del periodismo médico y farmacéutico en España, Madrid, Enrique Teodoro, Impresor, pp. 29-30). No viene citado por CALBET I CAMARASA, Josep M. y CORBELla I CORBELlA, Jacint (1982), (Diccionari biografic de metges catalans, Barcelona, Fundació Salvador Vives Casajuana,).

${ }^{88}$ SEREÑANA Y PARTAGAS, Prudencio (1881), La prostitución en la ciudad de Barcelona, estudiada como enfermedad social y considerada como origen de otras enfermedades dinámicas, orgánicas y morales de la población barcelonesa, Barcelona, Imprenta de los Sucesores de Ramírez y Ca, p. 99.
} 
se trataba tan sólo de mero proyecto no realizado? El primer reglamento del que tenemos constancia fue en efecto el Reglamento para la vigilancia y servicio sanitario de las prostitutas aprobado en Noviembre de 186789.

Guerola, quien sustituyó a Sepúlveda a principios de Febrero de $1864^{90}$, nos confirma no obstante la existencia en Barcelona de un sistema reglamentarista "establecido por (sus) antecesores", consistente en que "las dueñas y pupilas de estas casas pagasen un pequeño impuesto para pagar a los médicos que las visitaban y reconocían"91. La única reforma introducida por Guerola en 1864, y que califica de "reforma de moralidad", consistió en que "las mujeres pagasen directamente a los médicos, sin mediar como antes la mano intermedia de los empleados de policía, para evitar la sospecha de que se distrajese ese fondo de su verdadero objeto". Ocho médicos se dedicaban en 1864 a los reconocimientos periódicos de las prostitutas, repartiéndose los 8.000 reales recaudados semanalmente entre las prostitutas.

Pero los primeros conatos de reglamentación en Barcelona se deberían unos años antes al empeño reglamentarista de Martín de Foronda y Viedma, ex-Gobernador civil de la provincia en $1852^{92}$. Secretario interino del Ateneo de Madrid en Mayo de 1820, y Escribiente de la Escuela Nacional de Veterinaria en 1821, Foronda fue primero Gobernador Civil de Zaragoza en 1843-1844, asumiendo posteriormente el mismo cargo de nuevo en Zaragoza en 1851 y luego en Cádiz en $1852^{93}$. Y en 1860 propuso, desde su presidencia de la Sociedad Económica Barcelonesa de Amigos del País ${ }^{94}$, abrir una discusión sobre el tema "si sería conveniente prohibir de todo punto la prostitución, y en el caso de que no lo fuera, qué medios podrían adoptarse para que, sin ofender a la religión ni a la moral pública, cesara esta gangrena que corroe la

\footnotetext{
${ }^{89}$ Reglamento para la vigilancia y servicio sanitario de las prostitutas, Barcelona, Establecimiento tipográfico de Miguel Gonzalez y Sugrañes, 1867, 16 p. Ver art. 57, p. 16: "Queda derogada toda disposición de este Gobierno de Provincia, que se oponga al presente Reglamento". Fue derogado a su vez por el Reglamento de Higiene especial del 7-V-1870 (Barcelona, s.imp., 1870, 16 p.).

${ }^{90}$ SUAREZ, Federico (1985), "Estudio preliminar" a GUEROLA, A. Memoria de mi administración en la provincia de Zamora como Gobernador de ella desde 12 de Agosto de 1853 hasta 17 de Julio de 1854, Zamora, Instituto de Estudios Zamoranos Florián de Ocampo, pp. 40-42, y RISQUES, M. (1995), op. cit., p. 620

91 GUEROLA, Antonio (1866), Memoria de mi administración en la provincia de Barcelona como Gobernador de ella desde 5 de Febrero hasta 14 de Julio de 1864 (Madrid), ej. mecanografiado, cap. 55 ("Prostitución"), t. III, p. 56 (original depositado en la Universidad de Navarra, Pamplona. Cortesía de Manel Risques, Barcelona).

92 BENET, Josep y MARTI, Casimir (1976), Barcelona a mitjan segle XIX. El moviment obrer durant el Bienni Progressista (1854-1856), Barcelona, Curiel, t. I, pp. 39-42.

${ }^{93}$ Guía de Forasteros en Madrid, para el año de 1852, Madrid, En la Imprenta Nacional, p. 432; RISQUES, M., op. cit., p. 618.

94 Guía de Forasteros para 1864, pp. 728, 184 y 100 (comprobar). Ver GUEROLA, A. Memoria de mi administración en la provincia de Barcelona, op. cit., t. I, pp. 153-155.
} 


\section{JEAN-LOUIS GUERENAA}

sociedad en el germen de su existencia"95. Pero nada se hizo de forma práctica durante el largo mandato del entonces Gobernador civil Ignacio Llasera y Esteve (del 11 de Julio de 1858 al 14 de Febrero de 1863) hasta su sustitución por Sepúlveda ${ }^{96}$.

\section{LOS ÚLTIMOS AÑOS DE LA MONARQUíA DE ISABEL II (1864-1867)}

En los últimos años de la monarquía de Isabel II, algunas ciudades más reglamentaron la prostitución, por primera o segunda vez.

En 1864, se adoptó en efecto en Cádiz un segundo reglamento siempre calificado como el anterior de "represivo de la prostitución":

\footnotetext{
"La formación del presente Reglamento y las medidas que en él se establecen, no tienden de manera alguna a autorizar la prostitución, vicio reprobado por la moral y Religion: el reprimir aquella, el corregir en lo posible sus estravios, el organizar, reglamentar y vigilar médica y legalmente a las mugeres que se dedican a esta vida, y el proteger la salud pública evitando la propagación del mal venéreo y sus fatales consecuencias, es su único y exclusivo objeto"97.
}

Su responsable era el entonces Gobernador de la provincia - y también dramaturgo- - Antonio Hurtado y Valhondo (1825-1878), que ya había desempeñado idénticos cargos a partir de 1859 en las provincias de Albacete, Jaén (de Noviembre de 1860 a Julio de 1863) y Valladolid ${ }^{98}$. Hurtado fue Gobernador de la provincia de Cádiz tan sólo unos pocos meses, del 10 de Abril —sustituyendo a José María Palarea - al 29 de Julio de 1864, cuando se trasladó al Gobierno de Valencia ${ }^{99}$. Posteriormente, en 1866, fue diputado por la provincia de Cádiz, después de asumir el gobierno de la provincia de Barcelona del 28 de Junio de 1865 al 25 de Abril de 1866100.

95 SEREÑANA, P. (1881), op. cit., pp. 98-99.

${ }^{96}$ Guía de Forasteros para 1859, op. cit., p. 437; Guía de Forasteros para 1860, op. cit., p. 445. Brigadier en 1853, y General de brigada, Llasera ya había sido Gobernador civil de la provincia de Barcelona en 1843 y en 1855-1856 (BENET, J. y MARTI, C. (1976), Barcelona a mitjan segle XIX, op. cit., vol. II, pp. 49 y 561; RISQUES, M. (1995), op. cit., p. 614). Ver A.H.N., Gobernación. Personal, leg. no 284.

97 Reglamento represivo de la prostitución, Cádiz, Imp. de La Paz, 1864, p. 1.

98 Guía de Forasteros para 1860, op. cit., p. 446 (Albacete). Sobre la carrera política de Hurtado -pero sin que se mencione su paso por el Gobierno de Cádiz-, ver GARCIA CAMINO, Víctor-Gerardo (1977), Vida y obras de Antonio Hurtado. Aportación para su estudio, Cáceres, Editorial Extremadura, pp. 129-159.

${ }^{99}$ Boletín Oficial de la Provincia de Cádiz, nº 88, 12-IV-1864, p. 1, y n 26, 30-VII-1864, p. 1. Le sustituyó Antonio López de Letona.

${ }^{100}$ RISQUES, M. (1995), op. cit., p. 621. 
Los 85 artículos del reglamento de 1864 -casi tres veces más que en el anterior de 1861- estaban reunidos en seis secciones ("De la Oficina Sanitaria", "De las prostitutas", "De las casas de lenocinio", "Medidas sanitarias", "Disposiciones generales", "Correcciones y penas"). Pero ¿por qué un segundo reglamento en Cádiz, tan sólo tres años tras el primero, y derogado siete años después durante el Sexenio en $1871^{101}$ ? Seguramente la voluntad del Gobernador de controlar los fondos recaudados gracias a la reglamentación de la prostitución está en causa. Amén de reducir los gastos, reduciendo el número de facultativos encargados de los reconocimientos bisemanales (nueve en vez de "los catorce profesores higienistas en el día"), podemos constatar en particular la insistencia del reglamento de 1864 en fijar las sumas que se pedían a las amas y a las prostitutas: cuotas mensuales a las dueñas de casas de prostitución de 20 a 120 reales según la categoría (cuatro), cobradas "por quincenas adelantadas", para los reconocimientos médicos, y cantidades de 20 a 50 reales por gastos de registro, cartilla e impresión del reglamento. Las prostitutas habían de abonar además 10 reales por la cartilla, y las que disponían de domicilio propio 2 reales por reconocimiento. La secretaría del Gobierno civil quedaba responsable de dar "la inversión oportuna" a la recaudación que se obtenga por gastos, sin olvidar las a veces importantes multas (hasta 200 reales) impuestas por infracciones al reglamento, mientras que "la recaudación de los honorarios que se devenguen por los profesores higienistas en los reconocimientos y la recaudación de las cuotas fijas, su distribución y contabilidad, pertenecen exclusivamente al cuerpo médico-higienista"102.

Parece ser que también se reglamentó entonces la prostitución en San Fernando, situado a sólo $13 \mathrm{~km}$. de Cádiz (27.482 habitantes en 1860, 28.227 en 1900), y en donde residía el Capitán general de Marina. Según el higienista gaditano Pascual de Hontañón dos médicos higienistas efectuaban en Julio de 1864 reconocimientos médicos una vez a la semana a las prostitutas de San Fernando, lo que suponía la existencia de algún reglamento ad hoc en aquella localidad gaditana ${ }^{103}$.

$\mathrm{Al}$ poco tiempo, el Ayuntamiento de la vecina localidad del Puerto de Santa María, en la misma provincia (21.711 habitantes en 1860 y 20.120 en 1900), aprobó en Setiembre de 1864 bajo el mandato de José Francisco Barreda un reglamento con el mismo título significativo que el de Cádiz, y mera adaptación de éste ${ }^{104}$. Si sus 85

\footnotetext{
101 Reglamento de Higiene especial, Cádiz, Revista Médica, 1871, art. 83, p. 16.

102 DE HONTAÑON P. (1866), resume las principales medidas del reglamento gaditano en su Ensayo práctico sobre las enfermedades venéreas, op. cit., vol. 2, pp. 668-670.

103 DE HONTAÑON, P. (1865), op. cit., p. 50. El artículo viene fechado el 15-VII-1864. Ver también su Ensayo práctico sobre las enfermedades venéreas, op. cit., 1866, vol. 2, p. 667.

${ }_{104}$ Reglamento represivo de la prostitución para la ciudad del Puerto de Sta. María. Votado y aprobado por el Excmo. Ayuntamiento en sesión de 20 de Setiembre del corriente año, habiendo merecido la del Gobierno de provincia, en 7 de Octubre del mismo, Puerto de Santa María, Tipografía de Don Joaquín Caballero, 1864, 14 p. El Gobernador era entonces Francisco Fernández Golfín. Ver PAREJA ORTIZ,
} 


\section{JEAN-LOUIS GUEREÑA}

artículos se agrupaban en las mismas secciones, se pueden observar no obstante algunas diferencias, tanto en el número de médicos afectados a los reconocimientos de las prostitutas portuenses (sólo un numerario y un supernumerario), como en las cuotas mensuales de las amas de casas ( 3 categorías) que variaban de 30 a 90 reales. Se aludía por otra parte - caso que debía de ocurrir con frecuencia - a "las prostitutas transeuntes, o que vinieren a ejercer la prostitución por uno o más días, como sucede en los festivos o feriados del verano". Según un informe municipal de Mayo de 1875, este reglamento de 1864 "quedó abolido algún tiempo después", "bastardeado por causas que no son del caso"105. Y los ediles proponían más de diez años después el restablecimiento del reglamento.

Sin que exista reglamento, notemos que en la ciudad de Granada el Alcalde recordaba en un bando "de buen gobierno", proclamado en Diciembre de 1864, la vigencia del Código Penal de 1850, y en particular su artículo 485, según el cual "se castigarán con la pena de arresto de cinco a quince dias o una multa de 5 a 15 duros: (...) $8^{\circ}$ Los que infringieren los Reglamentos de policía en lo concerniente a mujeres públicas"106.

En 1865, el Gobernador de la provincia de Valencia (107.703 habitantes en 1860 y 213.550 en 1900 en la capital), Cástor Ibáñez de Aldecoa ${ }^{107}$, dictó por su parte el $1^{\circ}$ de Agosto unas normas relativas a la "prostitución pública"108, en el transcurso de una epidemia de cólera que asolaba la región levantina ${ }^{109}$, justificándose de antemano como siempre ante posibles críticas:

\footnotetext{
"La formación del presente Reglamento y medidas que en él se establecen, no tienden en manera alguna a autorizar la prostitución, vicio reprobado por la moral y religión: el reprimir aquélla, el corregir en lo posible sus estravíos, el organizar, reglamentar y vigilar médica y le-
}

Francisco (1988), "Mentalidad, religiosidad y moralidad pública: la prostitución en El Puerto de Santa María en el último tercio del s. XIX", Comunicaciones Presentadas al VII Congreso de Profesoresinvestigadores, Motril, Asociación de Profesores de Geografía e Historia de Bachillerato de Andalucía, pp. 497-500.

${ }^{105}$ A.M. Puerto de St ${ }^{a}$ María, Sección Sanidad, cit. por PAREJA ORTIZ, F. op. cit., 1988, p. 497.

${ }^{106}$ Bando de Buen gobierno, s.l. (Granada), s.imp., s.f. (1864), sin p. (Granada, 10-XII-1864, José Marín Sánchez) (B.U. Granada B-11-995 (51).

107 Sus antecesores en el cargo fueron Antonio Hurtado y Celestino Más y Abad, cuya paternidad en la reglamentación observamos ya en los casos de Alicante y Cádiz.

108 Reglamento para la prostitución pública en Valencia, s.l. (Valencia), Imprenta de Ferrer de Orga, 1865, 11 p., cit. por GARCIA FRAGUAS, J. E. (1908), Estudios y Observaciones de Amatoria Sexualis. I Amor libre y prostitución, Barcelona, Biblioteca de la Regeneración Física, s.f. p. 381.

${ }^{109}$ PESET, J. B. (1876), Bosquejo de la historia de la Medicina de Valencia, Valencia, Imprenta de Ferrer de Orga, pp. 262-263. 


\section{PROSTITUCIÓN, ESTADO Y SOCIEDAD EN ESPAÑA....}

galmente a las mujeres que se dedican a esta vida, y el proteger la salud pública, evitando la propagación del mal venéreo y sus fatales consecuencias, es el único y exclusivo objeto" 110 .

Al parecer existía ya sin embargo en Valencia, y desde 1863, una sección de vigilancia "especial" encargada de vigilar a las prostitutas como en Madrid ${ }^{111}$, y organizada de nuevo en 1865 :

"En la Secretaría del Gobierno de Provincia, y bajo la inspección inmediata de la Sección Central de Vigilancia, se establecerá una oficina compuesta de un Oficial, dos Celadores, un Escribiente y un Ordenanza destinada a llevar los libros y cuidar del exacto y constante cumplimiento de este Reglamento" 112 .

El Reglamento valenciano de 1865 , que se componía de 52 artículos con seis títulos ("Objeto y organización de la Vigilancia especial", "De las casas públicas y sus sirvientas", "De las prostitutas", "De los Médicos y de la vigilancia sanitaria", "Disposiciones generales", "De las correcciones y penas"), estuvo en vigor, al parecer, hasta $1879^{113}$. A su gestación contribuyeron como casi siempre los médicos de la localidad. En la sesión del 21 de Junio de 1862 del Instituto Médico Valenciano constaba ya en el orden del día la "necesidad hoy día existente de poner un coto en cuanto sea posible a la prostitución, por el inmenso perjuicio que está originando a la Sociedad en el sentido de la salud"114. Y en sesión de 20 de Mayo de 1865, N. Ferrer y Julve, al abordar el problema de la prostitución, proponía para precaverla, evitar y corregir sus consecuencias, "mejorar la educación, prolongar la tutela paterna, procurar la separación de sexos en los talleres, obligar a las mujeres al trabajo y retribuir éste convenientemente, sostener y propagar las casas de arrepentidas, no descuidar la educación religiosa, reglamentar la prostitución" 115 . La reglamentación le parecía imponerse como solución racional desde el campo de la higiene frente a "un mal incurable":

"Hoy día la prostitución está reglamentada en muchas capitales de naciones vecinas a la nuestra; lo está en nuestra España en determinadas localidades como en Madrid, Sevilla, Zaragoza, etc. ¿Por qué Valencia no ha de participar de este beneficio?”.

\footnotetext{
${ }^{110}$ Reglamento para la prostitución pública en Valencia, op. cit., 1865, art. 1, p. 3.

${ }^{111}$ Reglamento orgánico del cuerpo de vigilancia pública, 21-X-1863, op. cit., art. 10.

112 Reglamento para la prostitución pública en Valencia, op. cit., 1865, art. 2, pp. 3-4.

${ }_{113}$ Reglamento especial sobre las mugeres públicas en Valencia, s.l. (Valencia), Impr. de Emilio Pascual, 1879, 13 p.

${ }_{114}$ Boletín del Instituto Médico Valenciano, Valencia, t. VIII (1862-1863), p. 137.

115 Ibid., t. IX (1864-1866), p. 386. 


\section{JEAN-LOUIS GUEREÑA}

A los largo de veinte años, de 1845 a 1865, fecha de la entrada en vigor oficial de este reglamento valenciano y del quinto reglamento madrileño, eran ya por lo menos en unas catorce localidades españolas (de las cuales once eran capitales de provincia) en doce provincias, en las que se había reglamentado la prostitución, por disposiciones tomadas, bien por el Gobernador civil de la provincia, bien por el Alcalde de la localidad, con el visto bueno del primero.

Podemos añadir, ya poco tiempo antes del Sexenio, un reglamento para Barcelona, en donde había "Ilamado sensiblemente la atención de este Gobierno de Provincia, el estado del repugnante vicio de la prostitución en esta Capital (...)"116. Firmado en Noviembre de 1867 por el Gobernador civil de la provincia Romualdo Méndez de San Julián ${ }^{117}$, el reglamento mencionaba indirectamente, como ya lo hemos señalado las disposiciones anteriores.

Compuesto por 57 artículos, el reglamento se articulaba en torno a ocho puntos ("De la Comisión de Médicos-Higienistas", "Del Presidente", "De los MédicosHigienistas", "De la Inspección Especial", "De las Mancebías", "De las prostitutas", "Medidas sanitarias", y "Disposiciones generales"118). Un artículo intentaba "proteger" al hombre casado (o "viudo con hijos o hijo de familia") de enamorarse de una prostituta, sacándola del padrón especial para vivir amancebados"119.

Se adoptó también en 1867 otro texto en Vigo (provincia de Pontevedra), que no hemos conseguido localizar, y del que sólo tenemos noticias indirectas ${ }^{120}$. Se trataría del primer reglamento de la prostitución en Galicia ${ }^{121}$.

La reglamentación de la prostitución empezaba pues a ser un hecho relativamente generalizado en bastantes ciudades españolas en la segunda mitad del siglo XIX, en particular a finales de la monarquía de Isabel II, testimoniando de la influencia médica en la administración y en la sociedad (ver cuadro recapitulativo). Podemos observar que se trataba esencialmente de localidades portuarias - marítimas o fluviales-

\footnotetext{
${ }^{116}$ Reglamento para la vigilancia y servicio sanitario de las prostitutas, op. cit., 1867, p. 3. Reglamento curiosamente ignorado por SEREÑANA Y PARTAGAS, P. (1881), quien alude a "algunas disposiciones" dictadas "por los distintos jefes que en el período de 1868 a 1870 se sucedieron en el gobierno de la provincia" y a los reglamentos de 7-V-1870 y de 11-XI-1874 (op. cit., pp. 99-100 y 104-118).

117 Fue Gobernador de Barcelona del 31-VIII-1867 al 31-VII-1868 tras haberlo sido de Córdoba en 1865 y 1866 (RISQUES, M. (1995), op. cit., p. 621).

118 El punto $\mathrm{I}^{\mathrm{o}}$ viene como "Capítulo" y los demás como "Título". Lógicamente, a partir del $3^{\circ}$, los "títulos" habrían de ser "capítulos", lo que daría un capítulo I $\mathrm{I}^{\circ}$ con 2 títulos y 5 capítulos más, del $\mathrm{II}^{\circ}$ al VI".

119 Reglamento para la vigilancia y servicio sanitario de las prostitutas, op. cit., 1867, art. 52, p. 15.

120 J. ZAVALA, $\mathrm{M}^{\mathrm{a}}$. (1891), Consideraciones sobre la prostitución y sus reglamentos, op. cit., p. 71; RODRIGUEZ SOLIS, E. (1892), op. cit., t. II, p. 187 ("En 1867 apareció el Reglamento de la prostitución en la ciudad de Vigo"), y $2^{\text {a }}$ ed., op. cit., 1921, p. 246.

121 Para la época anterior, ver LOPEZ DE LA VEGA, José (1858), "La prostitución en Vigo", El Siglo Médico, Madrid, V, $\mathrm{n}^{\circ}$ 249, 10-X-1858, p. 326. Posteriormente, tenemos constancia de un reglamento en La Coruña en 1884, reeditado por el Ayuntamiento de Santiago de Compostela en 1886.
} 
PROSTITUCIÓN, ESTADO Y SOCIEDAD EN ESPAÑA....

(Alicante, Barcelona, Cádiz, Málaga, Palma, Puerto de Santa María, Santander, Sevilla, Valencia, Vigo), o de ciudades próximas a Francia (Gerona, Zaragoza), o sea de centros abiertos a la comunicación con el mundo exterior. También podemos apuntar que eran plazas militares, sede de varios cuarteles, donde se hallaba buena parte de la clientela potencial de los prostíbulos. No todas eran ciudades con una población importante, pero la casi totalidad de las ciudades más pobladas figuraba con una reglamentación más o menos completa (Madrid, Barcelona, Valencia, Sevilla ...) y, por lo general, muy similar. Destacaba por otra parte la fuerte presencia andaluza, con tres provincias (Cádiz, Málaga y Sevilla), y en menor medida catalana (Barcelona y Gerona).

¿Se conocía entonces el conjunto de esta reglamentación? En 1861, el médico Antonio Prats y Bosch podía reconocer así, pero sin entrar en mayores detalles, que "años atrás en algunas poblaciones se trató de organizarlas (las casas de prostitución), dotándolas de reglamentos mendigados al extranjero", aunque afirmaba a continuación que "unas y otras cayeron muy pronto en el olvido bajo el peso de la opinión pública"122. "En varias capitales populosas del reino", apuntaba por su parte Monlau en 1862 y desgraciadamente tampoco sin especificar, "se ha ensayado en estos últimos años, y se está ensayando hoy, el sistema de las matrículas y visita sanitaria de las rameras. De alguna capital sabemos que la Autoridad eclesiástica se ha opuesto, y con razón, a semejante tolerancia oficial; en otras capitales han caido en desuso, después de ensayadas, esas reglamentaciones que tan mal se compadecen con la moral pública y el buen ejemplo"123.

En cambio, sí se conocía y comentaba con frecuencia la reglamentación foránea, en especial la francesa, sin referirse a lo que sucedía en España: "Los lectores saben - aseguraba por ejemplo Roque Barcia en el relato de su viaje a París- que la prostitución se considera aquí como una industria, industria que tiene su matrícula, que está bajo la vigilancia del gobierno, pagando en trueque una contribución"124.

Pero ¿cuál fue la vida de las diversas reglamentaciones españolas? Desconocemos casi totalmente el alcance práctico de muchos reglamentos, o sea si llegaron a ser otra cosa que papel mojado en función de los cambios políticos ocurridos. Sabemos que por lo menos la temprana reglamentación zaragozana de 1845 sí se aplicó concretamente durante varios años. ¿Cabe suponer lo mismo de las demás regla-

\footnotetext{
122 PRATS Y BOSCH, A. (1861), La prostitución y la sífilis: Ensayo acerca de las causas de la propagación de las enfermedades sifilíticas y los medios de oponerse a ella, Barcelona, Librería de El Plus Ultra, p. 34. Ver también su réplica a la nota crítica del Doctor CHECA (en los Anales de Medicina, Cirugía y Farmacia) publicada por Monlau en El Monitor de la Salud, t. 4, n 8, 15-IV-1861, p. 87.

${ }_{123}$ MONLAU, P. F. (1862), Elementos de higiene pública o arte de conservar la salud de los pueblos, $2^{\text {a }}$ ed., op. cit., t. I, p. 400. no, p. 27.

124 BARCIA, R. (1863), Un paseo por París, Retratos al natural, Madrid, Imprenta de Manuel Galia-
} 


\section{JEAN-LOUIS GUEREÑA}

mentaciones? ¿Dónde, cómo y cuándo cayeron en "desuso", según la expresión utilizada por Monlau? La generalizada desaparición de los archivos de los Gobiernos civiles impide desgraciadamente en muchos casos disponer de la documentación primaria sobre el particular. No conocemos por ejemplo cartillas sanitarias ni registros de prostitutas para la época aquí enfocada.

Es de destacar por fin la proposición del gaditano Pascual de Hontañón en 1865. Preocupado por la relativa heterogeneidad de las normativas locales - cuando existían-, propuso entonces homogeneizar y generalizar para toda España la reglamentación de la prostitución, y concretamente la institución de médicos higienistas:

“Así, pues, hay poblaciones en España, donde la institución (de los médicos higienistas) ha recibido un grande impulso, otros en que sólo está tímidamente establecida y los más en fin, en que falta por completo.

Choca desde luego esta falta de armonía y uniformidad entre provincias que forman parte de una misma nación y obedecen a unas mismas leyes.

(...) Todo esto pudiera remediarse con solo que el Gobierno fuese como debía, el fundador y el director único de todos los médicos higienistas de la peínsula, dictando un reglamento, previamente discutido y meditado por una reunión de profesores competentes, y promulgado después en toda España, donde fuese obligatorio en todas sus partes, e inaccesible a toda modificación capaz de alterar la unidad de la ley"125.

Pero aún no había llegado la hora de un reglamento único y seguirían implantándose reglamentos de ámbito local durante el Sexenio y la Restauración.

\begin{tabular}{|c|c|c|c|}
\hline \multicolumn{4}{|c|}{ REGLAMENTOS DE LA PROSTITUCION (1845-1867) ${ }^{126}$} \\
\hline 1845 & (9-III) & 1. Zaragoza * (1) & (Antonio ORO, GC) \\
\hline 1847 & $(1-\mathrm{VII})$ & 2. Madrid * (1) & (Patricio de LA EsCoSURA, GC) \\
\hline 1854 & $(26-X)$ & 3. Gerona * (1) & (Joan BALARI y Josep LlaCH I SoliVA, A) \\
\hline & $(4-\mathrm{XI})$ & 4. Madrid * (2) & (Luis SAGASTI, GC) \\
\hline 1855 & & 5. Málaga (1) & (Cayetano CARDERO, GC) \\
\hline & $(31-X)$ & 6. Jerez (Cádiz) * (1) & (A) \\
\hline 1859 & $(30-\mathrm{IV})$ & 7. Madrid * (3) & $\begin{array}{l}\text { (Antonio AgUILAR y CORREA, Marqués } \\
\text { de LA VEGA DE ARMIJO, GC) }\end{array}$ \\
\hline & $(12-\mathrm{IX})$ & 8. Sevilla $*(1)$ & (Juan JiMÉNEZ CUENCA, GC) \\
\hline
\end{tabular}

125 DE HONTAÑON, P. (1865), "Institución de los Médicos Higienistas", op. cit., pp. 50-51.

${ }^{126} \mathrm{El}$ asterisco indica que se ha localizado una copia del documento. Entre paréntesis figura el número de orden por localidad, y a continuación el nombre de la autoridad firmante del reglamento y su calidad (GC= Jefe Político o Gobernador Civil; A= Alcalde). 
PROSTITUCIÓN, ESTADO Y SOCIEDAD EN ESPAÑA....

\begin{tabular}{|c|c|c|c|}
\hline \multicolumn{4}{|c|}{ REGLAMENTOS DE LA PROSTITUCION (1845-1867) } \\
\hline 1860 & & 9. Alicante (1) & (Celestino MAS Y ABAD, GC) \\
\hline 1861 & $(30-I V)$ & 10. Cádiz * (1) & (A) \\
\hline \multirow[t]{2}{*}{1862} & & 11. Santander * (1) & (A) \\
\hline & & 12. Palma (Baleares) (1) & $\begin{array}{l}\text { (Matías Edmundo TIREL, Marqués de } \\
\text { LOS UlaGARES, GC) }\end{array}$ \\
\hline \multirow[t]{2}{*}{1863} & & 13. Barcelona (1) & (Francisco SEPULVEDA, GC) \\
\hline & $(30-\mathrm{IX})$ & 14. Madrid * (4) & (Conde de EzPELETA, GC) \\
\hline \multirow[t]{3}{*}{1864} & (IV-VII) & 15. Cádiz * (2) & (Antonio HURTADO Y VALHONDO, GC) \\
\hline & & 16. San Fernando (Cádiz) (1) & $(¿ \mathrm{~A} ?)$ \\
\hline & $(16-\mathrm{IX})$ & $\begin{array}{l}\text { 17. Puerto de } \mathrm{St}^{\mathrm{a}} \text { María } \\
\text { (Cádiz) } * \text { (1) }\end{array}$ & (José FRANCISCO BARREDA, A) \\
\hline \multirow[t]{2}{*}{1865} & (1-VIII) & 18. Valencia $*(1)$ & (Castor IBAÑEZ DE ALDECOA, GC) \\
\hline & $(14-X I)$ & 19. Madrid * (5) & $\begin{array}{l}\text { (José Isidro OsORIO y SiLva, Duque de } \\
\text { SESTO, GC) }\end{array}$ \\
\hline \multirow[t]{2}{*}{1867} & $(4-\mathrm{XI})$ & 20. Barcelona $*(2)$ & (Romualdo MÉNDEZ DE SAN JULIAN, GC) \\
\hline & & 21. Vigo (Pontevedra) (1) & $(?)$ \\
\hline
\end{tabular}

\section{CONCLUSIÓN}

Aunque de manera mucho más discreta que en otros paises (como Francia por ejemplo), pero no menos real, el burdel tolerado formó plenamente parte del espacio urbano y social español dentro de lo que podemos considerar como la "edad de plata" de la prostitución reglamentada. Y la topografía prostitucional mantuvo por lo general sus espacios tradicionales a pesar de las medidas periódicas de expulsión de las prostitutas de sus zonas de implantación.

Implantado en casi un siglo, en los siglos XIX y XX (hasta 1956), ofrece perfecta cuenta el sistema reglamentarista contemporáneo de la importancia y del papel de la prostitución en las prácticas sexuales y sociales. Testimonia así mismo la voluntad del cuerpo social de hacer frente a los desórdenes de las conductas sexuales, de frenar el peligro de las enfermedades venéreas, y de conservar el orden moral vigente, integrando y marginando a la vez a las prostitutas. La época aquí enfocada, tras las primeras tentativas de la década moderada, demuestra la confluencia de intereses diversos para restablecer el sistema reglamentarista que había conocido su esplendor hasta el siglo XVII.

Necesaria o inevitable pero peligrosa, por ser considerada como elemento potencial de desorden, la prostitución debía ser pues, según las distintas administraciones en función a lo largo de la época considerada, como más generalmente durante la 


\section{JEAN-LOUIS GUEREÑA}

segunda mitad del siglo XIX y principios del XX, una actividad tolerada pero estrechamente controlada, así como imponible al igual que otro tipo de servicio. La generalización del sistema reglamentarista durante la monarquía isabelina, al igual que lo estaba ocurriendo en otros países, muestra claramente las presiones higienistas y administrativas para controlar una población marginal flotante así como el consenso social en la material, con no obstante destacadas oposiciones. También señala la importancia que venía cobrando la prostitución en la vida social así como los intereses cada vez mayores en juego. ¿Por qué privarse en efecto de los dividendos generados por la legalización de la prostitución?

Una sociedad burguesa urbana se estaba dotando entonces de sus diversos instrumentos de intervención y control del espacio social. La reglamentación de la prostitución en la época isabelina, en sus dos dimensiones (higiénica y policial) formaba claramente parte de este dispositivo social. Se trataba de una real operación de limpieza urbana paralela a la que también se realizaba entonces con los pobres y los "vagos" para construir nuevos espacios de sociabilidad urbana. En vez de encerrar a la prostituta en una casa de corrección o de expulsarla de la ciudad como se había venido haciendo desde tiempos atrás, se la recluía en una casa de prostitución limitando su libertad de circulación y controlando periódicamente su potencial capacidad de contagio. Al mismo tiempo, la tolerancia de la prostitución confirmó el lugar y el papel de los burdeles en la vida social de las principales ciudades españolas. 